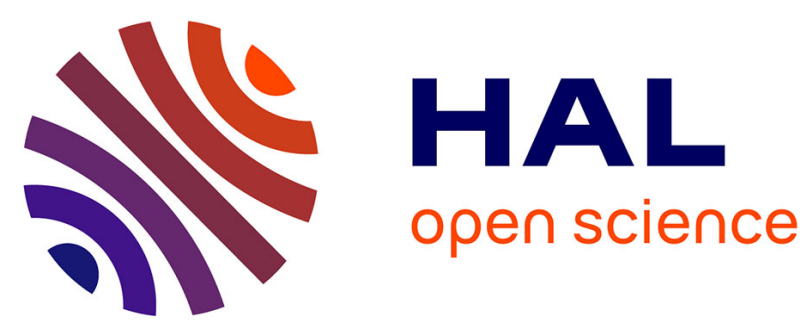

\title{
Inclusive innovation and the role of technological capability-building: The social business Grameen Danone Foods Limited in Bangladesh
}

\author{
Jahan Ara Peerally, Claudia de Fuentes, Paulo N. Figueiredo
}

\section{To cite this version:}

Jahan Ara Peerally, Claudia de Fuentes, Paulo N. Figueiredo. Inclusive innovation and the role of technological capability-building: The social business Grameen Danone Foods Limited in Bangladesh. Long Range Planning, 2019, 52, pp.101843 -. 10.1016/j.lrp.2018.04.005 . hal-03488478

\section{HAL Id: hal-03488478 https://hal.science/hal-03488478}

Submitted on 21 Dec 2021

HAL is a multi-disciplinary open access archive for the deposit and dissemination of scientific research documents, whether they are published or not. The documents may come from teaching and research institutions in France or abroad, or from public or private research centers.
L'archive ouverte pluridisciplinaire HAL, est destinée au dépôt et à la diffusion de documents scientifiques de niveau recherche, publiés ou non, émanant des établissements d'enseignement et de recherche français ou étrangers, des laboratoires publics ou privés.

\section{(ㄷ)(1) $\$$}

Distributed under a Creative Commons Attribution - NonCommerciall 4.0 International 


\title{
Inclusive Innovation and the Role of Technological Capability- Building: The Social Business Grameen Danone Foods Limited in Bangladesh
}

Jahan Ara Peerally (corresponding author) ${ }^{(a)}$

Claudia De Fuentes ${ }^{(b)}$

Paulo N. Figueiredo ${ }^{(c)}$

(a) Associate Professor, International Business, HEC, 3000, chemin de la Côte-Sainte-Catherine, Montréal (Québec), H3T 2A7, Canada, Tel: 514340 6578, e-mail: jahan.peerally@ hec.ca

(b) Associate Professor, Sobey School of Business, Saint Mary's University, 923 Robie St. Halifax, (Nova Scotia), B3H 3C3, Canada, Tel: 902420 5851, e-mail: claudia.defuentes@ smu.ca

(c) Full Professor, Brazilian School of Public and Business Administration (EBAPE) at the Getulio Vargas Foundation (FGV), Brazil Rua Jornalista Orlando Dantas, 30 -- 22231-010 -- Rio de Janeiro RJ, Brazil. Email: paulo.figueiredo@fgv.br

\begin{abstract}
This article examines how a least developed country-based social business first creates operational capabilities (OCs) and then, over time, builds innovative capabilities (ICs) to fulfil a social need, be self-sustainable and achieve inclusive innovation. This relationship is examined in Bangladesh's Grameen Danone Foods Limited (GDFL) by integrating the technological capability and inclusive innovation theoretical frameworks and by using data gathered through extensive fieldwork. Broadly, our findings show how GDFL built and accumulated basic and intermediate ICs to undertake innovative activities in all areas of operation. Specifically, our findings scrutinize the process in which a social business develops and organizes its resources to initially build OCs and engage in the creation of ICs through various learning mechanisms to deliver inclusive innovation. From this process, we also observe a set of unpredicted positive spillovers to the community, which expands the inclusiveness effect. The findings also suggest that having a social orientation, triggers the use of different resources from within and outside the firm to achieve inclusive innovation. We conclude by discussing the study's implications for scholars, policy-makers and managers of multinational's social businesses. We also highlight future research areas, and crucially those related to key emerging conceptual limitations of inclusive innovation and development.
\end{abstract}

Keywords: Technological capability-building; inclusive innovation; social business; multinational enterprises; learning; business models; social impact; Bangladesh. 


\section{Funding}

This research project was funded by the Research Office of HEC Montréal under the programme entitled 'Aide au démarrage au projets de recherche'.

\section{Acknowledgements}

In memory of Professor Jean-Claude Cosset, who supported this study as Director of the Research at HEC Montréal. His mentorship and integrity will be missed. Our study could not have been accomplished without the invaluable support of key professionals from Danone Group and, especially, from Grameen Danone Foods Limited in Bangladesh. We wish to thank in particular Guy Gavelle, Emmanuel Marchant and Emmanuel Faber. We also thank (i) Professor Flocki Taube (Université libre de Bruxelles) for connecting us to Danone in the first place; (ii) colleagues from the International Business Department at HEC Montreal for their valuable feedback on the paper's first draft presentation; (iii) Professor John Cantwell (Rutgers Business School) and Professor Yves Plourde (HEC Montreal) for their valuable input in addressing some key revisions; and (iv) the Editor and anonymous reviewers for their precious time and comments.

\section{Corresponding author's contact details:}

\section{Jahan Ara Peerally}

Associate Professor

HEC Montreal

International Business Department

3000, chemin de la Côte-Sainte-Catherine, Montréal (Québec) H3T 2A7

Téléphone : 514 340-6000, poste 6578 Télécopieur : 514 340-6987

Email: jahan.peerally@hec.ca 


\section{Introduction}

In the last decade, criticisms on approaches which aim for more inclusive economic growth, have emerged. Cannon's (1992) approach to corporate social responsibility (CSR) for example, has been criticized for being essentially corporate-centered and ultimately concerned with profit generation rather than with real inclusiveness (Ansari et al. 2012). The base of the pyramid (BoP) approaches have also been criticized, as contributing little to real inclusive growth since they are corporatecentric, top-down strategies that emphasize corporate profit generation by stimulating consumption in low-income populations through more affordable products and services (e.g., Arora and Romijn, 2011; Calvano, 2008; Karnani, 2007; Simanis and Hart, 2008). These approaches are argued as having limited capacity to deliver local skills development, real changes in living standards (Ansari et al. 2012), as well as concrete welfare in local communities (Hall et al. 2012; Radojevic and Peerally, 2014). Consequently, bottom-up approaches to inclusive growth, based on building intangible assets of local capacity for wealth creation, local project ownership and shared commitment, have emerged. In line with this, recent empirical contributions suggest that the effectiveness of inclusive business initiatives in $\mathrm{BoP}$ communities [including those led by multinational enterprises (MNEs)] in delivering inclusive growth depends on the extent to which such initiatives become increasingly community-centered, are committed to skills development, preserve the local social capital (e.g., Ansari et al. 2012; Bradley et al. 2012; Heeks et al. 2014), overcome institutional hurdles to inclusiveness (e.g., Mair et al. 2012), and balance economic growth with social and ecological pressures (Hall et al. 2012).

These contributions point to a promising avenue for researching the nascent field of businesses in inclusive innovation, and their role in fostering participation in high-growth, high-profit ventures by disenfranchised communities in the form of ownership, managerial control and supply-chain involvement (George et al. 2012). The existing literature has already begun to address this. In a special issue of Long Range Planning on business models, Yunus et al. (2010) present the social business model, as “a self-sustaining company that sells goods and services and repays its owners" investments, but whose primary purpose is to serve society and improve the lot of the poor" (p. 309). However, they do not delve into self-sustainability attainment and delivery of inclusive innovation by this model. Other articles in the special issue, which examine new business models for emerging economies and social uses, (e.g., Dahan et al. 2010; Thompson and MacMilan, 2010) also overlook capability-building processes that foster self-sustainability of such business models and their delivery of inclusive innovation. Other related studies argue that business models need technological innovation to succeed (e.g., Baden-Fuller and Haefliger, 2013; Teece, 2010). However, these studies 
assume the pre-existence of the technological capabilities (TCs) (e.g. Bell and Figueiredo, 2012; Bell and Pavitt, 1995) needed for basic operation of, and innovation in social businesses. They therefore neglect the processes by which operational capabilities (OCs) and innovative capabilities (ICs) are created through learning mechanisms and which then allow businesses to undertake innovative activities. Hence, a gap about the role of ICs for achieving innovations, including inclusive innovation, exists in the business model literature.

More recently, this gap was highlighted by scholars (e.g. Cozzens and Sutz, 2014) within the inclusive innovation literature. Additionally, this literature, and explicitly George et al. (2012), expand on the importance of knowledge creation, learning and capabilities as necessary for achieving inclusive innovation and generating positive impact for the stakeholders involved. They posit that capabilities and human capital are some of the crucial factors for enhancing the emergence and flourish of inclusive innovation. They also emphasize that research is required in order to understand the role of capabilities as drivers of inclusive innovation.

Our research explores this research gap and we argue that before social businesses can implement technological breakthroughs and innovative activities to deliver inclusive innovation, they first need to build up their TCs which involves both OCs and ICs. Thus, our study develops a conceptual framework by bridging the TC and inclusive innovation literatures. On the one hand, the TC literature helps us understand how a social business develops and organizes its resources to build OCs and ICs. On the other hand, the inclusive innovation literature helps us understand how a social business contributes to inclusive growth for its local communities through the achievement of inclusive innovation. Our study also contributes to a better understanding of the TC creation and accumulation processes in a social business for achieving inclusive innovation, by using an in-depth case study based on extensive fieldwork at Grameen Danone Foods Limited (GDFL) in Bangladesh. Our research question is: how does a least developed country-based social business create and accumulate TCs over time, to then fulfil a social need, be self-sustainable and achieve inclusive innovation?

The remainder of the paper is organized as follows. Section 2 presents the conceptual framework. Section 3 describes the research context and Section 4, the methodology. Our analysis is presented in Section 5, and Section 6 concludes with the implications of our study and the emerging conceptual limitations related to inclusive development and innovation. 


\section{A TC-Building Approach to Inclusive Innovation}

Apart from their mutual focus on innovation, the TC and inclusive innovation literatures also focus on the societal context and development. Compared to the neoclassical literature, evolutionary economists' work on TCs is much more social group-oriented, and typically sees the firm as a social community, [see for e.g. Kogut and Zander (1993, 1996) for key contributions]. Evolutionary economists have stressed the embeddedness of firms (and their capabilities) in the wider institutions and the locational social context (Freeman, 1995; Lundvall, 1992). They also stress the role of linkages between firms and non-firm actors when building capabilities, and the importance of the larger social environment in that process [see Murmann (2003) for a historical perspective in the German chemical industry]. They have also shown, initially through qualitative and later through quantitative studies, that building TCs in areas of production, triggers industrial and economic growth, and potentially social development. This process explains how some economies, such as the Asian dragons, flourished within a few decades of the Second World War from least developed economy status to newly industrialized ones. Their rapid growth rate sparked off a huge amount of research on the mechanisms of what was eventually termed catching-up development (Bell and Pavitt, 1995; Kim, 1997; Lall, 1992).

Evolutionary economists emphasized that catching-up entails concerted long-term efforts towards the development of social, institutional, organizational and technological capabilities. Consequently, they proposed that developing countries which are able to successfully build strong indigenous capabilities, have a higher probability of catching-up and closing the economic and industrial gaps with more developed ones. Concisely, these contributions and perspectives on TCs, highlight the need for social participation and socially generated objectives to play a part, and have inherently had the moral purpose to ultimately reduce poverty in least developed countries (LDCs) and developing countries by bringing about wide ranging industrial and economic development. However, these contributions have so far been grounded in a philosophy of solving overall socio-economic problems through industrial innovation and development, rather than exclusively looking at social problems through the lens of socially driven innovation initiatives, as in the inclusive innovation literature. More recently, the inclusive innovation proponents have emphasized the role of learning and ICs as necessary for solving social problems with novel solutions (Cozzens and Sutz, 2014; Santiago, 2014). 


\subsection{Inclusive innovation as a mechanism to achieve inclusive growth}

The literature on inclusive innovation (Foster and Heeks, 2013; Heeks et al. 2014; Santiago, 2014) stresses the importance of addressing complex social problems and generating social value, in particular for marginalized communities. Inclusive innovation as defined by Foster and Heeks (2013, p.335) is "the means by which new goods and services are developed for and/or by vulnerable populations living on lowest incomes. Contrasting conventional views of innovation, inclusive innovation explicitly conceives development in terms of active inclusion of those who are excluded from the mainstream of development, and refers to the inclusion within some aspect of innovation of groups who are currently marginalized".

Addressing complex social problems can be achieved in terms of generating new products or services for excluded populations, but in some cases, it might require developing grassroots solutions (Cozzens and Sutz, 2014; Westley, 2008). Westley and Antadze (2010) argue that grassroots approaches require involvement and interconnectivity among individuals and diverse organizations in order to provide novel solutions to complex problems, generating change at the social level, and in the process re-engaging vulnerable populations as active participants, contributors and beneficiaries. Similarly, Heeks et al. (2014, p.4) propose "a ladder of inclusive innovation”, based on different levels of involvement by marginalized communities. The first level of the ladder focuses on solving problems and addressing the needs of the marginalized communities, while the higher levels focus on actively engaging those marginalized communities in providing solutions to their social problems or needs.

Despite the richness of the relationship between inclusive innovation and inclusive growth, George et al. (2012) argue that several questions about this relationship remain unanswered by current organizational and management theories. To address this, they propose a theoretical lens from the subfields of organizational and management studies, involving the assembly, deployment and development of resources to enable organizational performance (e.g. Dosi et al. 2000; LeonardBarton, 1995; Wernerfelt, 1984) for achieving inclusive growth. These resources include for example, physical capital, human knowledge and skills, and organizational structures and processes. They suggest that firms secure the resources which are of value to them within a certain context, to then implement their activities and gain competitive advantage. They exemplify this within the context of inclusive innovation, as resources which give access to a logistics system for reaching the distant rural poor (George et al. 2012). They contrast resource advantaged and resource constrained environments by equating the former with large firms like Tata and the latter with individuals i.e. 
entrepreneurs. They propose that resource-based theories be applied to the context of large firms, and they recommend that future research focus on examining how absolute levels of resource deployments, in large firms, could enhance or impede low cost innovation, and the capabilities that allow low cost innovations to flourish.

We borrow from these vital notions; however, we adapt them to the idiosyncrasies of our study. The firm we study is small and lacks certain resources, but it is also the subsidiary of a large, resource advantaged MNE. Hence, it is intrinsically linked to a parent company and sister companies, from which it can potentially pool resources, depending on the specificities at hand ${ }^{1}$. Subsequently, we cannot categorize GDFL as being the same as an exclusively resource constrained firm, in the same manner as George et al. (2012) do. It cannot be categorized as being purely resource advantaged either. The literature which successfully combines, in countless studies, firm-level indicators such as firm resources, firm size and firm ownership structure - i.e. joint-venture (JV) or wholly owned subsidiary - in analyzing how resources are organized and developed in order to build capabilities for innovation, is the TC literature. Moreover, the literature has demonstrated that the TC framework is well adapted to firms from both developing countries and LDCs. It also clearly distinguishes between OCs and ICs - a distinction which is not explicitly covered by other frameworks. Essentially, we are contributing by assessing - as per George et al.'s (2012) set research agenda whether the instances of resource deployment in GDFL enhance or impede innovations (including inclusive ones), and the capabilities that allow its innovations to flourish for achieving inclusive growth. Additionally, we identify the knowledge creation and learning processes involved in building ICs and needed for achieving inclusive innovation and growth.

\subsection{TC-building in latecomer firms}

As previously mentioned, TCs involve both OCs (to use or operate current technologies and production systems) and ICs (to assimilate, adapt and change current technologies to create new technologies and develop new products and processes) to achieve innovation (e.g. Bell and Figueiredo, 2012; Bell and Pavitt, 1995). Even though our study is concerned with ICs, this analytical distinction is important because latecomer firms [i.e. firms that operate in developing and emerging economies (Kim, 1997; Lee and Lim, 2001)], generally begin as technology users, not innovators. This distinction helps to determine whether latecomer's capabilities grow over time into more innovative ones. Additionally, the distinction between these two types of capabilities may be

\footnotetext{
${ }^{1}$ Parent company refers to the investing entity within the MNE network and which owns and controls subsidiaries across national boundaries. Hence, sister company describes the relationship between subsidiaries within the MNE's network.
} 
blurred in practice, and where OCs may even contribute to the accumulation of ICs (Bell and Figueiredo, 2012).

TCs therefore include a stock of knowledge-related resources that permit firms to undertake operational and differing degrees of innovative activities. Such capabilities involve both human capital and organizational aspects (e.g. firms' internal and external organizational arrangements including routines, procedures and managerial systems) (e.g., Bell and Pavitt, 1993; Dosi et al. 2000; Dutrénit, 2000; Leonard-Barton, 1995).

The TC constructs for assessing firm-level innovation capabilities in advanced economies, are mainly based on quantitative measures such as $R \& D$ investment, $R \& D$ expenditures and patent grants (Hagedoorn and Cloodt, 2003). These measures are only useful once firms have developed their ICs to the point where they involve measurable capabilities in R\&D or recorded patenting. They, therefore, only reflect a fraction of a firm's innovative capability, or none at all for firms with nonR\&D-based ICs. Furthermore, by relying on aggregate R\&D-based measures of firms' innovation capability, a range of technological and innovation activities that are necessary to develop and produce particular products are neglected. These also do not capture the process of technological transformation within a wide spectrum of activities, especially those that precede $R \& D$ and are crucial to the initial growth of latecomer firms (Bell and Figueiredo, 2012; Bell and Pavitt, 1993).

These limitations were first addressed and overcome in the earliest studies on latecomer firms' innovation capabilities, by using qualitative (including case-based) assessments at the scale of TC levels (see review in Bell and Figueiredo, 2012). Latecomers are typically characterized by a low level, or even an absence of TCs, especially ICs, and by being resource-poor and initially imitative. This stream of qualitative research generated a comprehensive approach for operationalizing capability-levels based on revealed capability, rather than specifically identifying them in terms of particular quantities and qualities of human resources and skills. This approach identified levels of increasing novelty and significance of innovative activity and which then inferred that different capability levels underlie different types of innovative activities (Bell and Figueiredo, 2012). These methodological efforts led to the creation of a typology, developed by Lall (1992) and further refined by Bell and Pavitt (1995), which captures what firms are able to do in technological terms, by using a nuanced perspective of the levels of capabilities required to undertake innovative activities with different degrees of novelty. The typology therefore identifies IC levels which range from basic to world-leading and which are consistent with the Oslo Manual (OECD, 2005). This typology has 
been extensively used in both qualitative and quantitative studies and successfully adapted to different industries (Figueiredo, 2001; Peerally and Cantwell, 2012; Yoruk, 2011).

\subsection{The role of learning mechanisms in TC-building}

To build up their OCs and ICs, firms need to deliberately engage in technological learning (Bell and Figueiredo, 2012; Figueiredo, 2001). Learning is defined as the various costly and deliberate processes by which additional technical skills and knowledge are acquired by individuals and firms (Bell, 1984). It is cumulative and increases the firm's stock of knowledge (or capabilities), which, in turn, permits the firm to undertake innovative activities (Malerba, 1992). It involves the intensity, persistence and effectiveness with which firms manage, and invest in, the process of acquiring and creating the human resources and knowledge bases needed to conceive and implement their innovative strategies. Thus, learning is the process of acquiring, assimilating and sharing knowledge that builds up a firm's capabilities. Through learning mechanisms, a firm can acquire the tacit and codified dimensions of knowledge, or knowledge in disembodied and embodied forms (e.g., people and human capital). We adopt a comprehensive approach to learning which is consistent with that used in the literature on technological learning in developing and emerging economies (e.g., Bell, 1984; Bell and Figueiredo, 2012; Dutrénit, 2000; Kim, 1998). It encompasses all the ways in which a firm can acquire the knowledge, skills and other cognitive resources needed to engage in innovative activity. Thus, it covers both external sourcing and internal knowledge creation through several mechanisms (Cohen and Levinthal, 1990; Malerba, 1992).

Currently, there are empirical gaps in the inclusive innovation literature regarding the wider social processes that surround the diffusion and scaling up of inclusive innovations through distribution and use of new goods and services in poor communities. Cozzens and Sutz (2014) and Foster and Heeks (2013) purport that learning and capability-building fills these gaps since they play a key role in the diffusion and scaling up of inclusive innovations. Accordingly, our study emphasizes the learning mechanisms required for the diffusion and scaling up, as well as the achievement of inclusive innovations.

\subsection{Bridging the TC and inclusive innovation literatures}

The perspectives discussed above, frame the analytical focus of this article. Figure 1 is derived from bridging the TC and inclusive innovation literatures and depicts our conceptual framework. Even 
though the figure indicates a linear process, in reality TC-building and achieving inclusive innovation is not automatic and involve high levels of uncertainty at the organizational and contextual levels. Subsequently, this process is costly, involves deliberate efforts and is rife with problems and challenges, thus requiring feedback loops. The process is therefore expected to manifest itself in a non-linear fashion.

\section{[Figure 1]}

The conceptual framework starts by illustrating a social business (Yunus, 2010) with a dual mission. To achieve inclusive innovations (Heeks et al. 2014), it needs to first engage in a deliberate process of TC accumulation and learning (Bell and Pavitt, 1995). The type of social business, i.e. a subsidiary versus an entrepreneur, is a key determinant of the resources available to it, for building ICs and achieving inclusive innovation. At the beginning of the process, the social business takes stock of the level of existing capacities within the organization, and via linkages it then builds and accumulates increasingly advanced ICs. The accumulation of TCs requires a series of efforts to first build basic, then intermediate, and then advanced ICs (Bell and Pavitt, 1995). External sourcing includes all the organizations that are connected to the social business through formal and informal linkages, where it plays the role of either key support provider or collaborator. Internal sourcing refers to formal and informal linkages between the social business and the other entities within the firm (e.g., between the parent company and/or sister companies of a MNE, or between units of a large conglomerate).

Once the social business achieves a new product/service development, it is necessary as per Heeks et al. (2014), to scale it up. To do so, the social business uses different channels, either regular market channels, or engages the community and vulnerable populations, or it can even develop a hybrid channel which includes both market channels and vulnerable populations to ensure that the product or service reaches the target market. During scaling up, the social business continues to learn and build its ICs and achieves inclusive innovation. The process can continue further whereby achieving inclusive innovation contributes to inclusive growth, in part due to a set of unpredicted positive spillovers from the social business to the communities. The impact of this process is complex to measure, due to these unpredicted positive spillovers, and to the fact that not all impact are economic in nature. Indeed, impact evaluation remains a key item on the inclusive and social innovation research agendas. For example, the TEPSIE research initiatives (TEPSIE, 2014) contribute to the discussion on social innovation impact measurement, by indicating that social innovation unleashes unintended outcomes that bring both negative and positive consequences to society. Similarly, we 
argue that in order to measure the impact of inclusive innovation, it is necessary to first identify the multiple ways in which communities and stakeholders have unpredictably benefitted directly or indirectly from an inclusive innovation, for the betterment of their lives.

\section{Research Context}

We identified through a desk research, in June 2011, the only two known social businesses that spun off from Grameen and which engage in manufacturing. These social businesses are GDFL and Grameen-Uniqlo ${ }^{2}$, both located in Bangladesh. GDFL was created in 2006 and launched in $2007^{3}$, while Grameen-Uniqlo was launched much later in 2011. Since we needed to explore OC and ICbuilding and accumulation over a significant length of time, GDFL became the most rational option for our study.

At the time that GDFL was conceptualized, Bangladesh had a per capita income of US\$900, $31.5 \%$ of its population was living below the national poverty line, approximately $60 \%$ of the population was living on less than US\$2 a day ${ }^{4}$, and child malnutrition was a critical problem (Ghalib et al. 2009). Malnutrition is still highly prevalent in Bangladesh's population and contributes to a high child mortality rate of about $37.6 \%$ (under 5; per 1,000 live births) ${ }^{4}$. Despite reaching the lower middle-income country status in $2014^{4}$, UNCTAD (2016) classifies Bangladesh as a structurally weak and vulnerable LDC.

GDFL was established on 16 March 2006, following the signing of a memorandum of understanding between Danone - a large French MNE, present in more than 130 countries through more than 180 subsidiaries - and four Grameen companies: Grameen Business Promotion Services, Grameen Welfare, Grameen Energy and Grameen Telecom. It is a 50-50 JV where 50\% equity stake is with Danone and the remaining $50 \%$ is shared amongst the four Grameen companies. GDFL is a Danone foreign subsidiary and shares many of the privileges and advantages that other Danone subsidiaries enjoy. The higher equity stake held by Danone affords it a larger degree of control over the social

\footnotetext{
${ }^{2}$ For further information, see http://www.grameenuniqlo.com/en/about/history.html; http://www.grameenuniqlo.com/en/about/business.html

${ }^{3}$ For a detailed account of how GDFL was conceptualized, see Yunus $(2008,2010)$.

${ }^{4}$ Available from www.data.worldbank.org/country/bangladesh
} 
business. Hence, GDFL is managed day-to-day solely by the MNE, through the aegis of Danone Communities $^{5}$ - an investment fund created to support Danone's portfolio of social businesses.

GDFL is located in Betgari, a village on the outskirts of Bogra City in Bogra District, about 140 miles northwest of Dhaka. As per Yunus' (2010) seven principles of social business, it is to be a noloss, no-dividend business. Its objectives as listed on the Danone Communities website, reflect its dual mission (Batillana, et al. 2012; Voltan and De Fuentes, 2016) of responding to a social need whilst also achieving profits.

GDFL's head office is in Dhaka and oversees support activities such as sales, marketing (city and rural strategy), human resources and finance. In Bogra, GDFL covers the manufacturing, packaging, marketing (rural strategy and implementation), sales and distribution of fresh sealed yoghurt products, under the brand name Shokti+ or Shokti+Doi (i.e. Power+Yoghurt). The yoghurt was conceived based on the nutritional needs of Bangladeshi children - GDFL's target consumer group and contains essential vitamins and minerals lacking in the local population's diet. A clinical study by Sazawal et al. (2013) found that the Shokti+ had a positive impact, in several measures, on children who ate it for a year.

Being the first social business created, GDFL has been the subject of several studies. Previous studies focused on understanding the nature, operation objectives and implications of the social business, and identifying if social innovations have an impact on reducing poverty (Ghalib et al. 2009). Others focused on GDFL's strategy (e.g. Sardana, 2013), and found that it brings positive benefits to society such as reducing children malnutrition, generating employment, and bringing dignity to the poor. The most comprehensive publications on GDFL, however, include those of Humberg (2011), Humberg and Braun (2014) and Yunus (2008, 2010). These cover key aspects of GDFL's impact, and challenges for achieving its social objectives whilst balancing this with its need to remain financially sustainable. They provide important insights for understanding GDFL, but they do not address the process of TC-building, the learning processes necessary to build and accumulate ICs, or how ICs contribute to achieving inclusive innovation. Faivre-Tavignot et al.'s (2010) study on GDFL began to address the competency and learning issues but they do so from the perspective of the parent company i.e. the MNE Danone. Their framework is therefore one based on advanced firms from developed countries, and they suggest that firms developing proactive CSR strategies

\footnotetext{
${ }^{5}$ Danone Communities manages funds from both Danone and independent investors. For further information, see www.danonecommunities.com
} 
incidentally strengthen competencies needed for replicating breakthrough strategies. Unlike them, we focus on the social business perspective rather than the MNE and on the a priori capabilities required, and built, by GDFL in order to achieve innovations - radical, inclusive or otherwise.

\section{Methods}

Our research strategy and design were driven by the type of phenomenon at the center of the research: the nature of TC-building process and its underlying impact on achieving inclusive innovation. Firstly, since we focus on the evolution and transformation of TCs over time, the study required a research design that would allow us to closely observe this core phenomenon in a way that would go beyond snapshots, and examine how the different dimensions under analysis and their relationships played out in detail and across a reasonable time span (Miles and Huberman, 1994; Siggelkow, 2007). Thus, our study integrates a retrospective longitudinal approach, which led to the choice of a single case study design. Secondly, data was collected to identify significant changes in TCs on periods which we loosely conceived as the pre-launch to launch period (2005-2007), the post-launch period (2008-2009), and the take-off period (2010-2012). Thirdly, and given the scarcity of studies on the empirical link between TC-building, learning mechanisms and inclusive innovation, an abductive method - combining both inductive and deductive reasoning - was deemed most appropriate for analyzing the relationship between these three elements.

\subsection{Data sources}

The data sources included archival data, semi-structured interviews, informal discussions, nonparticipant observations and shadowing. The data collection started with a desk research and was followed by attendance at the Global Social Business Summit (Austria). At the summit, an initial interview was conducted with the CEO of Danone Communities and the Industrial Director of Danone Asia Pacific (IDDAP). During this occasion all information concerning GDFL, collected earlier through the desk research to ascertain that it was the appropriate social business to investigate, were validated.

The IDDAP was identified as the key interviewee for the main fieldwork, due to his involvement with GDFL prior and during its lifetime. With over 40 years of industry experience, most of it within Danone, he was described by Yunus (2010, p.56) as “Danone's gifted engineer/designer". He also conceived and launched the GDFL plant, and would provide crucial information related to the longitudinal aspect of our study and help identify key GDFL informants. The main fieldwork took 
place during February and March 2012 at the GDFL factory in Bogra and the head-office in Dhaka. The time frame, data collection techniques and interviewees are detailed in Table 1.

\section{[Table 1]}

\subsection{Data collection}

At the onset of interviews, all informants were asked about their level and field of studies (to ascertain, if their skills were upgraded at GDFL through additional training and studies), employment history and number of years of experience (to probe interviewees on what learning experiences were newly acquired by them at GDFL or in a prior employment, and also to assess inter-firm learning), and the industry of previous employment/s (to assess intra/inter-industry learning).

We adapted Bell and Pavitt's (1995) framework and its levels of TCs to our study (see Figure 2). Our framework presents the levels of TCs, the technological functions of the social business and illustrative examples of revealed capabilities, which we refer to as indicators. These were validated with the IDDAP prior to the fieldwork.

\section{[Figure 2]}

Interviews with the IDDAP, GDFL technical and production employees and an ex-Plant Manager, applied the following guidelines to assess relative levels of TCs. Firstly, interviewees were asked open-ended questions - in ascending order and related to their functional area - on all the capability indicators in our framework. Based on their responses, further elaborations were sought on the significant technological milestones achieved during GDFL's lifespan (e.g. major plant performance improvements, major process modifications, or specific landmark projects). Secondly, they were explicitly informed that these milestones should reflect a manifestation of GDFL's, and hence the employees' increased skills level to handle and improve the firm's technology.

Furthermore, interviewees were asked about the types of adaptation made to technologies, process, production, equipment and products, including if and when they introduced new processes/products, and whether these were distinctly different from the existing ones on the local or global market. Using technological novelty/uniqueness as an indicator of GDFL's achieved IC level, the interviewees were asked to describe which kinds of technical changes they implemented. They had 
to explicitly distinguish between no changes, new-to-the-social business, new-to-the-local market/economy, or new-to-the-world. Interviewees were also asked about product quality certifications acquired.

GDFL's Managing Director and the IDDAP were asked additional questions about the skills, knowledge and resources required - pre and post GDFL's launch - for decision-making, investment, feasibility studies, project preparation and implementation, training and recruitment and engaging in detailed engineering. This helped to compare the level of those capabilities, pre and post launch, as well as over GDFL's remaining lifetime. Distinction was made between no changes in knowledge and resources and new-to-the-social business, new-to-the-local market/economy, or new-to-theworld. The Milk and Farm Development Officer, Sales Manager and Rural Manager, were asked additional questions related to linkage development with suppliers, customers, the community and institutions with the aim of transferring or acquiring TCs and to ascertain spillover effects.

The conceptual distinction between external and internal types of learning mechanisms was explained with examples, to interviewees. They were asked questions on what and how specific employees learned from different sources, in relation to the different capability indicators, and how this learning process was manifested in concrete terms. Focus was also placed on reversed learning linkages, whereby the role of GDFL as a source of capabilities - both intra/inter-firm and to the community - was also investigated.

Technical staff were probed on episodes related to trial and error efforts, troubleshooting, on-site problem solving, internal sampling or even R\&D activities, and the level of continuity of resources devoted to searching for and leveraging knowledge from foreign and/or local sources. The Managing Director, Milk and Farm Development Officer, Sales Manager and Rural Manager were asked additional questions related to the types of learning mechanisms and spillover effects related to development of linkages with suppliers, customers and the community at large.

\subsection{Data analysis}

Following a deductive approach, we analyzed the data on the nature of TC-building process and the underlying learning mechanisms. Through inductive analysis, we investigated the link between the former two and GDFL's achievement of inclusive innovation.

\subsubsection{The nature of TC-building and the learning mechanisms}


This first step of the data analysis fell into three stages. First, the transcribed records of interviews were converted into an analytical-descriptive chronology for each technological function. Second, by analytically coding interviewees' responses to questions on their functional areas, we classified the data by capability levels (as in Figure 2). We applied deductive reasoning for classifying both the capability levels and learning mechanisms. For example, some indicators - such as plant site selection - categorically fall within the 'operational capability level'. While other indicators, such as those related to changes made to machinery or products, can be classified under differing capability levels. As explained in Section 4.2, the level of novelty/uniqueness of technological changes described by interviewees, which can range from minor adjustments to more advanced, and possibly entirely new, reconfiguration involving new processes, products and engineering solutions, enabled us to code and classify the data within the corresponding capability level. Thus, if interviewees stressed that they continued to use their pre-existing process and production organization without introducing any changes or achieving performance improvements, this particular GDFL activity would be classified at the lowest level - the 'operational capability level'. If employees undertook minor and incremental modifications to existing designs, that were new-to-the-social business, this GDFL activity would be classified at 'basic innovation capability level', and so on. The coding process applied to all the capability indicators in our adapted framework. However, GDFL did not have to comply with all indicators under each function to be placed within a category of capability level, since the manifestation of one indicator is sufficient to confirm that the firm is operating at that level.

Third, we qualitatively categorized the learning mechanisms according to the importance ascribed to them by the interviewees in relation to GDFL's TC-building efforts. Interviewees' explanations on the sources for new technical insights, skills and knowledge and for overcoming concrete problems, provided evidence on the nature of learning mechanisms employed. A given learning mechanism was interpreted as present if it was emphasized as having played an important role by the interviewees and as absent if they did not ascribe any importance to it. We followed the list of learning mechanisms from Bell and Figueiredo (2012) and by relying on our analytical-descriptive chronology, these learning mechanisms were matched, using deductive reasoning, to the TC levels and functions, derived from stage two above. This process led to the creation of four figures (Figures 3 to 6), one per technological function, each comprehensively demonstrating along three time periods, all the learning strategies used and the process of OC and IC-building by GDFL. We also summarize these findings in a narrative. 
Through a systematic triangulation effort, additional information was gleaned from the documentation in order to corroborate the findings. Intense efforts were made to minimize inaccuracy and bias associated with accounts of past events and we also incorporated triangulation cross-checks to deal with recollection issues and discrepant information. These were later verified through follow-up interviews with the IDDAP, in Paris (see Table 1).

\subsubsection{Achieving inclusive innovation}

Inclusive innovation was conceptually analyzed as concurrently involving the products developed, the elements necessary for scaling up the inclusive innovation and the active engagement of different stakeholders from the community by GDFL. So in the second step of our data analysis, we use the analytical-descriptive chronology and Figures 3 to 6, to build matrix data displays whereby the data was analyzed by grouping them according to their role in achieving inclusive innovation. The analytical-descriptive chronology, Figures 3 to 6 and matrices, were used as the basis for allowing the emergence of findings related to the link between GDFL developing and organizing its resources to build ICs and achieving inclusive innovation and social impact. Hence, the key findings from this data analysis process emerged from, and were grounded in empirical observation (Eisenhardt and Graebner, 2007; Siggelkow, 2007).

This process was guided by the following enquiries. What are the outcomes of GDFL's innovative activities i.e. meeting its social need, sustainability, achieving inclusion? Which dimensions of ICs become more relevant to GDFL when delivering inclusive innovation? What is the impact of these innovative activities on the communities around GDFL? Is the impact long-term and is its nature social, economic, a spillover?

We present and discuss these findings through an integrative analysis, resulting from an iterative process of cycling back and forth between the raw interview data, the analytical-descriptive chronology, Figures 3 to 6 , the matrices, the existing literature and the emerging results.

\section{TC-Building and Learning Mechanisms for Inclusive Innovation}

Figures 3 to 6 comprehensively cover all the technological activities and learning efforts undertaken by GDFL. They illustrate that, from the pre-launch period to 2012, GDFL built OCs, as well as accumulated basic and intermediate ICs to undertake innovative activities in all its functions. To complement these figures, we summarize our findings through a narrative, based on each technological function (as per Figure 2). Concomitantly, the figures and narrative let us show how 
OCs and ICs, across functions and time, are built by GDFL and the types of learning mechanisms involved. At the end of this section, we present an integrative analysis to investigate the link between GDFL's learning and TC-building path and its achievement of inclusive innovation.

\subsection{Project management and equipment-related}

GDFL was built to supply 3000 tons of yoghurt per year to 3 million inhabitants in Bogra within a radius of 30 to 50 kilometers. It plans to use the profits earned in Bogra to build another 49 factories across the country each supplying within their own 30 to 50 kilometers radius. GDFL is the first producer and seller of sealed yoghurt in Bangladesh. The initial estimated cost for the project by the JV partners was $€ 1.2$ million. Since Danone usually invests about $€ 37,500,000$ for a factory of this capacity, an investment of $€ 1.2$ million seemed feasible. In March 2006, Danone Singapore conducted the feasibility studies for GDFL and determined that, in order to amortize the investment, it should be further reduced to $€ 600,000$.

\section{5-2006: OC level}

Most of the technical expertise for project execution, during the pre-launch phase emanates from Danone. However, for non-technical issues, Danone relied partly on its JV partners. For example, in the project execution phase Danone drew the specifications for the plant's site selection, but it used local experts from its Grameen partners to help with the site search, selection and purchase (Figure $3)$.

\section{[Figure 3]}

In parallel to the site selection, the IDDAP worked on the other project management aspects, related to processes and production technologies. The IDDAP had to ensure that GDFL's equipment were adapted to Bogra's technological reality, and be easy to repair. Suppliers of machinery were required to have a representative in Bangladesh. Otherwise, GDFL built on existing capacities and developed capabilities for troubleshooting, servicing and maintenance of utilities, by hiring and training a Maintenance-in-charge who was a university graduate and who had previous work experience at BRAC Dairy, Bangladesh's second largest dairy company. During this stage, the IDDAP also hired and trained a key local professional - a Plant Manager - and together with the Maintenance-incharge, they will launch GDFL. The IDDAP took several measures to keep costs down. He searched for and purchased inexpensive utilities from India, Bangladesh and China. He contracted a local Bangladeshi engineer and owner of a welding company to assemble the systems' production process, 
utilities and packaging machinery. He also contracted a local to make cable trays to carry electrical wires throughout the factory, saving more than $€ 20$ per meter.

\section{7-2009: Basic IC level}

In this period, there were several opportunities for technology acquisition and for learning by doing (Dutrénit, 2000). One example is the acquisition of a used ammonia compressor from a ship cemetery and its repurposing to feed GDFL's cold room, which proved to be a creative learning process and indicates how GDFL organized and deployed resources in order to lower costs. This low-cost innovation in a physical system represents the main innovative activity for this function and period.

The IDDAP trained the Bogra management team at the plant on process design and purchasing of process equipment. He commissioned a Chinese integrator to draw up the production process for GDFL. The suppliers of process equipment and packaging equipment were also independent Chinese businesses outside of Danone's supplier network. Using Danone's suppliers for most, if not all of GDFL's purchasing and sourcing activities, was expected by the parent company, since its suppliers have been vetted through decades of mutual business dealings. These suppliers are therefore considered as being compliant with Danone's norms. However, the IDDAP argued that such an expectation would impede the social business, in terms of keeping expenditures low and respecting the investment amount, since Danone's vetted suppliers were costly. So it was negotiated that GDFL would strive to independently organize and develop its resources in order to meet its objectives (Leonard-Barton, 1995) and it would decide when to rely on its parent and sister companies.

By February 2007, the plant began production with a total of 30 employees, half of whom were engaged in process and production activities. The IDDAP invited a team from Danone Indonesia for 15 days, to train the local Bogra employees on launching the plant. The Indonesian team included the subsidiary's director, and the quality control, maintenance and production personnel. They were selected since their subsidiary, which opened in 2004, resembled GDFL's technological level the most. The training was an opportunity for knowledge acquisition and sharing, and thus contributed to IC-building. The several instances of training within this function and period (shown in Figure 3), illustrate GDFL's initial contributions to Bogra's development of innovative human capital. 
By 2010, GDFL had begun testing and creating a new-to-the-world dairy pouch product with low milk content. This pilot pouch project led to learning and equipment-related IC development. Since this product has higher viscosity than yoghurt, a new pump, sterilizer and packaging machine had to be installed as part of the process and production organization. In order to run the pilot project, a temporary packaging system - the U-Flex - was ordered from India. The U-Flex is a standard piece of equipment used for dry powdered products such as detergents that are packaged at room temperature; it was not conceived for the use intended at GDFL. The pouch product is liquid and must be packed at $75^{\circ} \mathrm{C}$ to avoid problems related to bacteria and mold. Since no equipment existed on the global market for packaging a hot liquid product, the U-Flex was modified at GDFL for this purpose. Several of the spare parts in this modification process were especially designed, ordered and made in Bangladesh, based on the specifications provided by GDFL. The pilot project also required the acquisition and installation of a tubular sterilizer which was donated by Danone Germany. It was autonomously modified and installed by the Maintenance-in-charge, who explained, “...I didn't know how to do it. I took it apart and put it back together and that's how I learnt how to design and install it" (Interview, Bogra). The revamping of such equipment without technical assistance and the low-cost innovative use of the U-Flex implies that GDFL now operates at the intermediate IC level. The learning mechanism was mainly internal whereby there was a process of innovative knowledge generation within GDFL from interactions between the IDDAP and the technical GDFL team through learning by doing activities with increasing levels of difficulty and reverse engineering (Lee and Lim, 2001). These led to the development of innovative human capital through increasing the experience and skills of GDFL's technical employees, who undertake more complex tasks, and of local businesses who gain new knowledge as they are required to develop spare parts for the U-Flex.

To replace the U-Flex when the pilot project is successfully concluded, GDFL works with an Indian supplier to develop a new-to-the-world equipment - the Hassia. In this process, Danone gains advanced ICs in new technology development through GDFL's collaboration with the Hassia supplier. The Hassia supplier also benefits from its interactions with GDFL. Both Danone Algeria and Danone India, which also aim to produce the pouch product benefit from the technology as well. The Hassia is therefore a low-cost, reverse, and new-to-the-world innovation.

By late 2012, GDFL had its stock of qualified professionals and was investing in the acquisition and assimilation of new knowledge. For instance, the Managing Director (originally from Danone) hired only university graduates for the Dhaka Management Committee which consisted of a Finance Manager, Supply Chain, Sourcing and Supplier Development (SSD) Manager, Marketing Manager, 
Human Resources Manager and Retail Manager. For the exception of the Marketing Manager, they were all Bangladeshis. These new recruits visited the parent company and/or other Danone subsidiaries to receive training. The Managing Director explained that, "These training opportunities allow GDFL managers to connect with the Danone network and develop key competencies” (Interview, Dhaka).

Within this time period, GDFL developed the project management and equipment-related capabilities needed to independently implement the construction and start-up of a second GDFL factory located near Dhaka, and for the continued growth of the Bogra plant. These capabilities were accumulated, as shown in Figure 3, through a combination of external knowledge acquisition and internal knowledge-sharing processes (Dutrénit, 2000).

\subsection{Process and production organization}

\section{7: OC level}

Prior to starting production in February 2007, the process for GDFL, which had been designed by the IDDAP and the integrator, was first tested at the latter's facility in China and then shipped to Bogra. Once assembled, the process was deemed too complex and through the joint efforts of GDFL's and the integrator's teams, it was further simplified. This learning by interacting was an important process of external knowledge acquisition by the GDFL team from the integrator's team. As shown in Figure 4, it also involved internal knowledge acquisition by GDFL, through learning by doing innovative activities (Lundvall and Johnson, 1994). The main type of innovative activity in this instance involved designing and setting up a low-cost efficient organizational process.

\section{[Figure 4]}

In setting up the process, the IDDAP and Danone focused on several cost-cutting measures, such as reducing energy consumption. The standard industry yoghurt-making process consumes a substantial amount of energy, involving heating and cooling in three stages of the process. After fermentation, it is vital to cool the yoghurt down to $20^{\circ} \mathrm{C}$ in order to maintain its $\mathrm{pH}$ at 4.5 and prevent overfermentation. Following a request from GDFL, Danone Paris' R\&D department generated a culture (Dream Culture) that automatically stops fermentation at $\mathrm{pH} 4.5$, without additional cooling. This innovation which significantly reduces the use of energy, radically changed the existing industrywide yoghurt-making process. The Dream Culture is a low-cost, radical and reverse innovation for 
Danone, only made possible through GDFL's effort in reducing costs associated with its process and production organization.

\section{8-2009: Basic IC level}

During the post-launch period, GDFL encountered various challenges which became opportunities for learning and capability-building. One example relates to the acquisition and set-up of a packaging automated system based on a programmable logic controller (PLC). The IDDAP opted for a packaging machine - the Zhongya - from an independent Chinese supplier, outside of Danone's supplier network. In parallel, a decision was made to use biodegradable pots for GDFL's yoghurts. At the time, only two suppliers in the world produced biodegradable plastic, while the packaging equipment, the Zhongya, was not designed to process biodegradable plastic. The IDDAP stated, "There are two suppliers... one in the US and a Chinese one...I opted for the Chinese one, ... which makes biodegradable plastic cutlery used in airplanes. They never made yoghurt pots before. I also discussed with the Zhongya supplier and they agreed to adapt their machine for this biodegradable plastic. We tried it and it worked really well" (Interview, Bogra). Only by organizing its resources independently of its parent company, that these vital interactions unfolded and enabled the GDFL team to understand the principles of both the Zhongya and the biodegradable plastic, through learning by operating, learning by adapting and learning through interaction (Lee, 2010).

GDFL also developed the capability to independently reduce the production rejection rate, through learning by experimentation and trial and error. For example, GDFL had a yoghurt viscosity problem in 2011, and this resulted in a high rejection rate. Through interactions with the IDDAP, the quality control team learnt how to standardize milk before starting the process in order to eliminate such viscosity problems. By organizing its resources and learning, and through interactions with the IDDAP and by relying on quality control employees with previous dairy industry experience, GDFL achieved an average rejection rate of less than $1 \%$ for the finished yoghurt product.

Following a $100 \%$ increase in milk price in April 2008, along with the fact that GDFL was not yet self-sustainable, the GDFL JV partners, in consultation with Muhammad Yunus, decided that the business should expand its customer base to include those with a higher purchasing power. GDFL would therefore produce and sell premium yoghurt at a premium price in major cities such as Dhaka, Chittagong and Sylhet through large supermarkets. Thus, in 2009, GDFL began developing a premium yoghurt to increase revenue. This led to further capability-building within the process and production organization function. 


\section{0-2012: Intermediate IC level}

The newly created premium products required the creation of a cold chain for its delivery to the different Bangladeshi cities. This process was independently implemented and managed at the level of GDFL by the senior Quality Control Executive. In addition he trained the junior Quality Control Executive and other new recruits on the main steps in undertaking an audit of the cold chain from Bogra District to Sirajgong District, 65 kilometers apart. He was also responsible for training the seven GDFL Laboratory Technicians. He asserted that his previous work experience at BRAC Dairy, paved the way for him to learn new product and process capabilities at GDFL.

The development and management of a cold chain, led to experience acquisition by the technical team, through knowledge articulation and assimilation, as well as learning through internal training and knowledge codification. The outcomes firstly include innovative human capital through the increased experience and skills of technical GDFL employees, who undertake more complex tasks and secondly organizational innovation, in terms of the creation of a cold chain, which increases sales and profits for GDFL thereby allowing it to pursue financial sustainability.

\subsection{Product-centered}

\section{5-2007: OC level}

During this period, GDFL accumulated capabilities both by drawing on Danone's internal knowledge network, to comply with the MNE's food and safety standards, and through local knowledge-acquisition and -assimilation efforts. For example, before the plant began production, the yoghurt was formulated in the GDFL laboratory and sent to Danone Spain, where the first approved product sample was conceived and shipped back to GDFL. Once the factory was operational, trials were run in Bogra with the local milk, and the yoghurt was adapted to the local milk's quality (see Figure 5). The local milk is low in protein, so the Bogra team autonomously ran tests and incorporated extra protein in the product formulation.

\section{[Figure 5]}

\section{8-2009: Basic IC level}

Market tests revealed that the yoghurt did not meet with local tastes, due to its low sugar content. Through a process of local and internal knowledge acquisition, the GDFL team came across a local natural sweetener, date molasses. However, Danone and its subsidiaries had never used date 
molasses, so Danone Spain had to test and approve it as a sweetener. Thereafter, the new yoghurt formulation with date molasses, and an increased sugar content, underwent further trials at GDFL. This demonstrates GDFL's capabilities for incremental product quality improvement and minor product adaptation, thus leading to a low-cost and incremental product innovation.

By March 2009, in order to meet the strategic decision of targeting premium consumers in cities, the product range was increased to include valorized mango- and strawberry-flavored yoghurts. Subsequently, GDFL also introduced extra-protein plain yoghurt. GDFL created, in-house, this new line of premium yoghurt and autonomously undertook the testing and formulation for the new flavors. The learning mechanisms involved local and internal knowledge acquisition based on searching and learning-by-experimenting in GDFL's laboratory leading to an incremental product innovation.

\section{0-2012: Intermediate IC level}

By 2010, GDFL had to become Hazard Analysis and Critical Control Points certified (HACCP) since it was targeting more consumers in big cities. Danone shared the specifications with GDFL's quality control team who autonomously implemented this certification process. This allowed the team to capture and embed knowledge received from Danone. The HACCP implementation is an organizational innovation with implication for improved product quality and safer, more efficient process and production organization. It also leads to intermediate IC-building (Bell and Pavitt, 1995). Since GDFL was the first local yoghurt producer, it drew up the yoghurt specifications and standards and shared them with the Bangladesh Standard Testing Institute (BSTI), thereby generating knowledge spillover to a local institution. Thus, GDFL's quality control capabilities relied on an internal knowledge socialization process for the HACCP and a process of knowledge codification from which the BSTI benefited.

The pilot pouch project (mentioned in section 5.1) also highlights the accumulation of innovative product-related capabilities for GDFL. Unlike the Shokti+, this pouch product, if launched on the market, would be stored, distributed and sold at ambient temperature with a 20-day shelf life. The senior Quality Control Executive stated, "This product is important for our social business because it allows us to reach remote rural areas where people living in poverty don't have refrigerators" (Interview, Bogra). 
The local inputs for this product, including the cereals, were sent to Danone Germany where the first product formulation was made. The protocols and formulation were then sent to GDFL and the quality control team implemented them. The Bogra team made further adaptations in terms of process and flavors. These process and product adaptations, and trials, in the creation of this new-tothe-world product and the team's participation in the production feasibility studies confirm that intermediate ICs have been attained for the product function. This new product development entails knowledge creation by R\&D through interactions between Danone Germany's R\&D unit and GDFL's team. The pouch product is a low-cost innovation which reduces production costs and expands the disenfranchised consumer base, while also including premium customers, therefore contributing to the achievement of GDFL's dual mission. It is also a reverse innovation, since the product is adopted by two Danone BOP subsidiaries, Danone Algeria and Danone India.

\subsection{Developing linkages with the local community}

GDFL has since its launch, organized its resources and developed numerous external linkages with NGOs, farmers, local institutions, and other members of the community. This sub-section focuses on the key interactions that led to learning for capability creation by both GDFL and community members.

\section{7-2008: OC level}

This period is represented by several challenges, two of which are introduced in this time period and tackled in the following time periods.

First, the acquisition of milk - which represents $80 \%$ of total inputs - has always been a challenge for GDFL. When it first began operations, GDFL developed linkages with local NGO farming organizations which acted as intermediaries between individual farmers and itself for the supply of milk (see Figure 6). Several factors forced GDFL to revisit this milk-sourcing model in the next time period. These include a fresh milk shortage in Bangladesh and a 100\% increase in milk price in 2008; low milk production by local cow breed; increasing competition from dairy companies in Dhaka; and ongoing competition from the informal sector which purchased $90 \%$ of the local milk production. 


\section{[Figure 6]}

Second, GDFL had envisaged that it would reach its village-based targeted consumers - nutritionally vulnerable children - through a rural network of village ladies who would sell the yoghurt, daily, on foot and door-to-door in Bogra District. Thus, GDFL would recruit, train and supply the village ladies with yoghurt. GDFL partnered with Grameen Bank in an attempt to recruit 'Grameen Ladies' women who are borrowers from Grameen Bank. Aside from recruitment issues, GDFL did not have the capabilities to retain these Grameen-Ladies. GDFL decided to organize its resources to develop its own ladies' network aptly named the Grameen-Danone Ladies.

\section{9-2010: Basic IC level}

Following the milk crisis of 2008, GDFL changed its sourcing model, and developed two types of sourcing. The first type involved cutting out the intermediaries and having the farmers directly sell their milk daily to the factory. The second type was based on the concept of chilling centers. Four hundred independent micro-farmers across Bogra District would deliver their milk to collection points manned by Gowalas - milk collectors. From the collection point, the milk is delivered to two chilling centers opened in Sariakandi in 2009 (a sub-district of Bogra) and in 2010 in Rangpur District each at 20 kilometers from GDFL. GDFL hired and trained four chilling center operators s as well as the Gowalas who would deliver the milk to the chilling centers. Implementing this sourcing model led to reverse learning by the chilling center operators and Gowalas who were trained in hygiene and basic accounting practices and in conducting density and adulteration tests. So there was a process of improved human capital and innovative organizational process development (Perez, 1988), through the introduction of new-to-the-social business chilling centers.

GDFL also hired and created a team who would be present in the field and who would work on improving the recruitment and retention of Grameen-Danone Ladies. This team, under the leadership of the Rural Manager, developed a profile of the types of ladies who would be most appropriate for selling yoghurt on foot. They also devised ID/product cards, which would enhance the GrameenDanone Ladies' sales techniques. Interviews with the Rural Manager revealed that one critical barrier to sales, was the inability of the ladies to retain product information. So the ID/product cards were created to overcome this barrier, since the ladies and the consumers could read the product information from the cards. When these steps proved to be successful both for recruitment and for retention, they were applied to expanding the Grameen-Danone Ladies network to three other districts. This illustrates organizational innovation for improving an internal GDFL practice, and 
which carries an element of human capital improvement whereby the ladies learnt new skills, and about the importance of nutrition.

The presence of GDFL in Bogra has contributed towards developing the capabilities of other members of the community as well. The Rural Sales Manager revealed that until 2010, it was a challenge for GDFL to track the Grameen-Danone Ladies' sales progress to the villages, simply because the number of villages within Bangladesh's districts is unknown. Through funding from the United Nations Development Program (UNDP) a consultant conducted a digital mapping project of the villages and their locations within Bogra District. In order to implement the project, GDFL hired a team of students from Bogra University to work with the UNDP consultant. Through this project, GDFL gained capabilities in digital mapping while the students gained practical experience both in implementing a digital mapping project in the field and in other management skills. The project was repeated for two other districts and involved the same students. This illustrates reverse learning by GDFL and the Bogra University students from the UNDP consultant, and the process through which GDFL developed basic IC involving innovative human capital for the community and innovative organizational process for the social business.

\section{1-2012: Intermediate IC level}

After GDFL successfully changed its sourcing model, it continued its efforts to secure milk from the market. In this bid, Danone sent its Farm Sourcing Director, from Danone Paris, to train GDFL's Milk and Farm Development Officer. This training was geared towards transmitting technical knowledge on methods for increasing milk productivity and organizing farmers so that the milk collection process becomes more efficient. The technical support provided by the Milk and Farm Development Officer, became an important incentive for farmers to sell their milk to GDFL. Moreover, GDFL took on a - what we term - knowledge brokering role by connecting the farmers to various local institutions, such as the Bangladesh Livestock Research Institute (BLRI) which developed a quality feed for cows at a low price. The most significant technical support to the farmers came in the form of artificial insemination. This interaction allowed the farmers to increase their productivity, and to double their herd within two years. Simultaneously, GDFL was able to increase the number of farmers it sourced from and thereby increasing the quantity and quality of milk. The main innovative activities within this function and period include organizational innovation for GDFL by cutting out intermediaries and working directly with farmers and the improvement of human capital in terms of the farmers who acquired better cow management skills. 


\subsection{Integrative analysis: inclusive innovation and social development by GDFL}

In the following analysis, we present our findings regarding the link between GDFL's learning mechanisms and specifically its TC-building process and its achievement of inclusive innovation. By carefully separating our findings into relationships between TCs, learning and outcomes for local development, we were better able to discern the process through which GDFL develops and organizes its resources to build ICs and deliver inclusive innovations and social development to its local communities.

GDFL engaged on a path of learning and building product-centered TCs, which allowed it to create two new products to achieve inclusive innovation i.e. the in-house original formulation of the newto-the-local-market Shokti+ and the new-to-the-world pouch product. These affordable products are within the reach of those living in poverty and in isolated rural areas where there is no electricity. The positive long-term contribution to social development of these inclusive innovations is in the form of nutritional improvement for malnourished children, as found by Sazawal et al. (2013) in their initial clinical trial.

Financial constraints coupled with the lack of appropriate local technical human resources, motivates GDFL to engage in the co-development of technology and processes and to source locals for the development of spare parts. These efforts (under the project management and equipment-related technological function) lead to the use of businesses outside Danone's vetted supplier network. These include dealings with a Chinese integrator, the co-development of the Hassia, and development of spare parts locally for the U-Flex and the tubular sterilizer. By deploying learning mechanisms related to shared inter-firm capabilities (Bell and Pavitt, 1993; Leonard-Barton, 1995;), GDFL is able to continue delivering its inclusive innovation since a low-cost, simplified process and the increased sales of the new pouch product are key in keeping the social business profitable and on the way to sustainability. There are also unpredicted positive externalities which result from these efforts. These include (i) the creation of business and learning opportunities for Bangladesh and other developing country firms which would have otherwise gone to large Western MNEs; (ii) increasing sales and profits for Danone Algeria and Danone India's BOP activities due to their adoption of the Hassia and (iii) increased earnings for the Hassia supplier as the new equipment is commercialized and sold to other clients globally. 
Our findings reveal that irrespective of the level of capability (OC, basic IC or intermediate IC) or functions, the consistent contribution to local development in delivering GDFL's inclusive innovation relates to innovation in and improvement in human capital (Lall, 1980; Perez, 1988). GDFL organizes its resources to develop human resource capabilities through training from parent or sister companies, on the job learning and training from the IDDAP or suppliers, troubleshooting product, process and production-related issues and reverse engineering. This innovation in human capital is key, as not only it is in line with one of GDFL's objectives (to improve the community's living conditions by creating jobs that raise the living standard and enhance the social fabric and the region), but also because the contribution goes beyond this objective. In relation to GDFL's employees, and specifically those in management and technical positions, such development of innovative human capital is important as it promotes long-term local growth and development through increasing productivity of labor and capital. Furthermore, it contributes to the industrial development of the region/country through the movement of innovative human capital from one firm to another, as it is also an upgrade in the knowledge and skills that individual employees bring to the firm in the form of know-how, creativity and the ability to identify and exploit opportunities and ideas. In fact such inter-sectoral movement in innovative human capital from GDFL has already occurred. Our interviews with GDFL's ex-Plant Manager revealed that in his subsequent position as Chief Engineer at the Dhaka Ice Cream Industries Limited, he built and adapted a mini-replica of GDFL's process to ice cream production, as part of a pilot project. This spillover effect for intersectoral industrial development, between GDFL and a domestic firm, is another example of an unpredicted positive externality.

Similar human capital related effects are associated with the Grameen-Danone Ladies, the chilling center operators, the Gowalas and the farmers. In these cases, there is an improvement in human capital whereby these previously disenfranchised individuals are now included in a process of acquiring new skills and knowledge which either empower them and/or increase their earning power. The ladies, who would have otherwise remained homebound, unemployed and financially dependent, are learning new skills and about the importance of nutrition. Thus, by delivering its products through a network of rural ladies, GDFL involves these community members in the diffusion and scaling up of its inclusive innovation, and contributes to their income and empowerment. There is additional job creation and income generation for the rural disenfranchised such as the chilling center operators and the Gowalas. Similarly, the acquisition of better cow management skills, increases the earning power of farmers. These elements together, contribute in the long-term social development by raising the living standard and enhancing the social fabric of the region. 
Human capital related effects are also associated with the Bogra University students. In building its TCs for tracking the Grameen-Danone Ladies within the districts through digital mapping, a positive unpredicted spillover to the community includes providing hands-on work experience to Bogra University students who earn an income and acquire practical skills which may open unpredicted career opportunities to them. GDFL therefore organized its resources and built ICs for digital mapping, which allowed it to deliver its inclusive innovation, resulting in the better monitoring of Shokti+ sales and thereby expanding its intended effect of nutritional improvement for malnourished children.

The attainment of GDFL's dual mission and the delivery of its inclusive innovation, were severely threatened by the milk crisis of 2008. GDFL built capabilities internally, in order to overcome this threat. First, it pooled resources from its parent company to train and significantly upgrade the Milk and Farm Development Officer's skills. GDFL also developed direct linkages in the community with dairy farmers, and local institutions and agents such as the BLRI and the artificial inseminator. The farmers benefitted from unpredicted positive spillovers through various types of technical support which simultaneously increased the quantity and quality of their herd and milk. Similar positive spillover effects with local institutions are seen, for example, through sharing quality standards with the BSTI. By building internal ICs and linkages with the community, GDFL is able to deliver locally recognized safe products and achieve inclusive innovation that is socially and economically sustainable. The enduring long-term outcome of pursuing its inclusive innovation, in this case, is an improvement in the region's livestock which benefits society in general.

Finally, when we assess which dimensions of ICs become more relevant to GDFL when delivering its inclusive innovation, or as per George at al. (2012) which instances of resource deployment in GDFL enhance innovations, and the capabilities that allow innovations to flourish for achieving inclusive growth, we observe the following. All technological functions contribute to the development of OCs and ICs and the achievement of inclusive innovation. However, resource deployment within the 'project management and equipment' and the 'developing linkages with the local community' dimensions have the highest instances of generating capabilities that allow innovations to flourish for achieving inclusive innovation and inclusive growth. With the former, the capabilities allow for innovations within GDFL to then achieve sustainability and inclusive innovation. With the latter, the capabilities allow for inclusive growth, as it is the only dimension 
within which there is the highest instances of human capital innovation or improvement for the local community.

There are, however, some caveats concerning our findings. As previously described in Figure 1, the processes of TC accumulation and learning are far from linear, unproblematic, and automatic. Our findings indicate that GDFL faced several challenges including lack of physical components and materials to construct and start up the plant, lack of local knowledge to run the plant and organize suppliers, difficulties to adjust production such as high rejection rates, problems in adjusting yogurt quality and composition to meet local taste, difficulties in training processes, and the recruitment of Grameen-Danone ladies for the creation of a sales network. Even so, GDFL was able to accumulate ICs up to the intermediate level (Level 3) across four technological functions. Being a MNE's social business subsidiary seems to have contributed to overcoming those challenges: GDFL drew on capability and expertise from its parent company and sister subsidiaries. Additionally, it was run by a technically competent and entrepreneurial management team with an impetus to engage in effective learning to accumulate ICs.

Another challenge included resolving the strategic tensions resulting from achieving its dual mission. As noted in our findings, by 2009-2010 GDFL had not broken-even due to several factors including cost and shortage of milk. It is only by reviewing its dual mission - and including the commercial mission of selling premium yoghurt to premium consumers - that it was able to become financially sustainable and attain its social mission. This solution, although obvious in retrospective, was nevertheless challenging for the Grameen JV partners and Danone's main executives, as they strongly and ideologically believed that GDFL's only purpose in Bangladesh was to supply fortified yoghurt to disenfranchised malnourished communities.

GDFL took seven years to move from operational level to intermediate IC level across four technological functions. To sustain such capability level and to eventually move to the advanced IC level (Level 4), GDFL must upgrade the effectiveness of its learning processes. Considering that the TC-building process is not linear nor automatic, it is not possible to say whether GDFL will sustain, deepen or even weaken its ICs. Therefore, our findings permit us to conclude that GDFL is a case of relative success in terms of TC-building. Its social, economic, commercial successes, and even its technological sustainability will depend on the effectiveness of its management.

\section{Implications and Conceptual Limitations: A Call for Future Research}


In this section, we conclude by discussing the main contributions and practical implications of our study. We also highlight future research areas related to the role of TC-building for social businesses. Lastly, we discuss key emerging conceptual limitations related to the notions of inclusive innovation and development, and provide further research directions which are critical for a congruent evolution of this field.

\subsection{Practical and empirical implications of TC-building in social businesses}

Our study has several contributions and implications. Firstly, and by fulfilling a research agenda set by George et al. (2012), our study helps both scholars and managers understand how different learning mechanisms and the process of capability-building, enable a social business to achieve innovative performance and self-sustainability to deliver inclusive innovation. Hence, we show as per George et al. (2012) how capability-building allows low-cost innovations to flourish and the underlying processes by which inclusive innovations are achieved. Additionally, we demonstrate that through building OCs and ICs, GDFL achieved inclusive innovation at different levels of Heeks et al.'s (2014) ladder for inclusive innovation. GDFL addresses the first levels of the ladder by solving a social problem and fulfilling a social need for Bogra's marginalized communities. It addresses the higher levels of the ladder, when it actively engages and involves the different marginalized community members in providing solutions to their social needs. In sum, by developing its TCs, GDFL contributed to local inclusive innovation for example, by producing lowcost innovative, nutrient-rich products for local vulnerable consumers; by employing/engaging and training people from the local communities (employees, Grameen-Danone Ladies, farmers, students, chilling center operators, Gowalas); by improving quality of life; and by developing the capabilities of both local and independent foreign suppliers.

Secondly, our study expands the TC research field boundaries beyond traditional business firms. Furthermore, it sheds new light on the underdeveloped research area related to the intricate relationship between capability-building and inclusive innovation. Our study also informs scholars and managers on how inclusive innovation is able to generate change by connecting local actors and re-engaging vulnerable populations as active participants and contributors, and thus generating meaningful and sustainable change at the social level (Westley, 2008). Lessons can be derived by managers from every step of GDFL's capability-building process, ultimately leading to GDFL's inclusive innovation - largely linked to human capital development - and sustainability. 
Thirdly, our study contributes to the inclusive growth literature in showing that there is a third type of organization involved in inclusive development, i.e. the subsidiaries of MNEs, and that these cannot always be deterministically classified by size or resource availability. This has implications for the managers of socially driven MNE subsidiaries. It shows how in several instances, GDFL independently organized and developed its resources and in other instances, like those related to employee training, it relied on the MNE's resources. Since resource availability differ greatly across MNEs, managers must assess what they can, or need to draw from their parent companies and sister subsidiaries, especially in relation to the local context and the challenges they face for achieving inclusive innovation and contributing to social development.

Fourthly, by identifying the accumulation of the different types and levels of ICs in GDFL, we show how these ICs are a locally driven source of positive spillovers for the host economy. By engaging in learning processes and accumulating ICs, GDFL has independently of its parent company, influenced both local and foreign suppliers and triggered their innovative activities. In other words, instead of passively receiving directives from its parent company, the social business subsidiary actively and independently engaged in IC development, thus creating a potential source for spillover to its host economy and further contributing to inclusive growth. Therefore, this study highlights the level of autonomy required by socially driven subsidiary managers in the decision-making and control aspects, despite compliance requirements imposed by the parent company.

Fifthly, understanding the process of TC development by such socially driven subsidiaries is necessary for guiding both developing country and LDC-based policy-makers in taking comprehensive measures for involving MNEs in achieving local development and social change. Furthermore, we draw policy-makers' attention on the importance of inclusive growth measures that go beyond the mere consumption of affordable goods and services. Real inclusive growth is derived from the involvement of local communities in skills development, entrepreneurial practices, the supply chain, employment and various types of innovative activities. Hence, TC-building processes at the level of social businesses contribute to the delivery of such inclusive innovation. Policies should be designed to provide support to social businesses for managing their learning mechanisms in order to create and accumulate ICs, and for implementing learning mechanisms across different levels of stakeholders, with particular attention to the most disenfranchised community members in order to generate inclusive innovation and contribute to inclusive growth. GDFL's experience goes beyond creating affordable consumption: its nutrient-rich yoghurts have been proven by Sazawal et al. (2013) to have significant biological effects on the children in its communities by improving their 
health status and cognitive skills development. These biological benefits will undoubtedly have further unpredicted positive social effects over the long term.

With regards to future studies, it must first be noted that existing innovation studies have focused on analyzing the effect of TCs on firm performance (by using various indicators such as exports, competitiveness, number of new products, sales, revenues, profits), but not on an organization's social performance. The analysis of social performance remains contested due to its multiple and often unpredicted effects and social spillovers to the community. For the same reason, impact evaluation remains a salient gap in inclusive innovation studies. Our study contributes to the identification of unpredicted direct and indirect positive spillovers to the community, and of the community members that benefit from those spillovers. It therefore sets the ground for future studies that aim to evaluate the impact of inclusive innovation and other grassroots innovations on society.

Future research could also explore sources of TC development, in particular the role of the various learning processes in influencing the way social business accumulates, or fails to accumulate, OCs and ICs. It could also investigate the role of other factors that shape the process of technological development in social businesses, such as leadership and management styles, and the role of local institutional frameworks, including policies and their effectiveness. In addition, impact measures should consider the effects of learning, capability-building and spillovers from this process.

\subsection{Emerging conceptual limitations about inclusive innovation and development}

Through conducting this study, we unveiled some key conceptual limitations related to the notions of inclusive development and inclusive innovation. As we previously mentioned, the last decade has seen the emergence of criticisms on approaches - such as CSR and BoP - which were incipiently aimed at more inclusive development. Similar criticisms, for example, have been made by Escobar (2011, 2015) about the sustainable development movement. He purports that the sustainable development movement, when considering the political actors involved (such as MNEs, governments, NGOs, international institutions), was riddled with tensions and contradictions from the outset. This led to the movement being flawed from the start, amounting to reducing sustainability - rather than increasing it. He argues that the discourse on growth can underpin very different values and agendas, and can also be co-opted and captured by those actors who are interested in maintaining the status quo, and that this in turn can bring negative implications for 
development. He therefore calls for more critical approaches to sustainable development including de-growth.

Similarly, while discussing innovation for development within a larger framework, Pansera and Owen (2016) contribute to the debate on de-growth and technology. Our study and results resonate with their position, whereby they indicate that innovation for development should not be seen as delivering affordable goods to poor consumers, as this view does not contribute to adequately grasping or commanding the critical components for reducing poverty or inequality. They contribute to the debate on de-growth and technology by suggesting that alternative ways of framing technology can actually coexist, and the problem that needs to be solved is not one of bringing affordable products, but one that builds knowledge within communities.

A key foundation of inclusive innovation is technology, and as we have shown in our study, this technology is embodied in people, organizations and physical systems. However, technology ${ }^{6}$ through firms can have varying impact. While we look at TC creation and its positive spillover effects into a vulnerable community, we acknowledge that the introduction of technological innovations in developing countries is driven by a different factors, not always leading to the alleviation of poverty and the creation of value for vulnerable or marginalized communities. Hence why, Pansera and Owen (2015), for example highlight that the process of achieving inclusive innovation in Bangladesh's resource constrained environments is subject to multiple barriers. Additionally, Cirera and Maloney (2017), indicate that innovation both in developed and developing countries can generate unpredicted outcomes, and some of which can generate further inequality. Radojevic and Peerally (2014), on the other hand, dispute wholesale claims in the extant reverse innovation literature about its ability to reduce poverty in the BoP. While Cozzens and Thakur (2014) have also cautioned against the potential negative effects of different types of innovation. In light of such unpredicted effects of innovation, there is an emerging interest by some academics [such as Escobar $(2011,2015)$ and Pansera and Owen $(2016,2018)$ ] to adopt a more critical

\footnotetext{
${ }^{6}$ Information and communication technologies, through the emergence of the information revolution, was also believed to be a tool for the decimation of poverty (Purcell and Toland, 2004). However, Graham (2011) when discussing the pertinence of the digital divide for development, state that the Internet and World Wide Web have not done away with the importance of geography. In other words, poverty is more of spatial problem of uneven development rather than a temporal modernization one whereby the poor have to eventually catch up with the technology. They argue that the digital divide should be pluralized, localized and grounded in more appropriate spatial frameworks in order to overcome geographic disadvantages which perpetuate and exacerbate poverty.
} 
approach regarding growth and development. Similarly, we argue that the notions of inclusive innovation, through technology, and as a consequence the notion of inclusive growth must be more critically considered, by building on the discussion of de-growth. Such an approach to future studies will only serve to nurture the field of inclusive innovation and development.

Furthermore, the conceptual notion of inclusiveness itself, must be challenged in future studies. Expost analysis, we discerned that some aspects of GDFL's experience, and possibly other similar social businesses, may be - allegorically - less inclusive. GDFL is the first producer of Western yoghurt in Bangladesh and its entry on the market led to the comparison of its Shokti Doi with the local Mishti Doi (Humberg, 2011). Mishti Doi, translated as sweet fermented yoghurt, is a local Bangladeshi dessert, sold informally by street vendors, for immediate consumption. These street vendors, like the Grameen-Danone ladies, fit Tobias et al.'s (2013:730) definition of social entrepreneurs, that are in effect "ordinary entrepreneurs" who tend to subsist in conditions of desperate poverty. Since the Mishti Doi is informally sold, it is not regulated by local institutions in terms of quality, food safety or market share. As such, it is not known whether GDFL's entry into the Bangladeshi market, with its well-structured campaigns emphasizing the safer, healthier Shokti Doi has had any negative impact on those vulnerable social entrepreneurs and their livelihoods. Alternatively, it is possible that as GDFL evolves, it will engage these Mishti Doi producers into its value chain. Thus, we call for more critical research that focuses on those that may potentially be excluded or further marginalized, as a result of the introduction of inclusive innovations within an economy. Moreover, inclusiveness should entail including all or, at least, most alternatives to generating development and reducing poverty. As such, future studies on inclusive development should focus on the potential alternatives that might compete with the inclusive innovation or inclusive solution that is being examined and, why those are not valid or why they were excluded by businesses and policy-makers alike.

Finally, while we and others have referred to Foster and Heeks' (2013) definition of inclusive development when studying its link to inclusive innovation, the nature of growth itself within the inclusive development literature has not been fully conceptualized. In other words, growth encompasses several measures such as in GDP, income, human development and so on. Our study, like most prevailing ones on the same topic, focuses mostly on a cropped snapshot of the sustainable human development aspect of GDFL's experience - that is the better nourishment of vulnerable children in the short-term with potentially more pervasive human development effects in the longterm - and micro positive spillover effects into the community. However, we cannot boast that our 
study, nor that the extant literature, answer the larger questions - within both the micro and macro contexts, - of those related to the effect of such social businesses in significantly and uniformly lifting large vulnerable populations out of poverty. Thus, the nature and conceptualization of growth within the inclusive development literature must be fine-tuned.

To conclude, one can argue that bringing about inclusive growth that is equally shared and in a pervasive manner across large populations is more of a political mandate related to states and supranational institutions that regulate state policies, than the role and mandate of technology through firms. Thus, future research must engage more with the critical de-growth and postdevelopment literatures in order to ensure that the current inclusive development movement, like the sustainable development, CSR or BoP one, does not lose momentum or become synonymous with maintaining the status quo for the poor and vulnerable as well as for the various private or public actors that promulgate an inclusive development agenda. 


\section{References}

Ansari, S., Munir, K., Gregg, T., 2012. Impact at the 'bottom of the pyramid': the role of social capital in capability development and community empowerment. Journal of Management Studies, 49(4), 813-842.

Arora, S., Romijn, H., 2011. The empty rhetoric of poverty reduction at the base of the pyramid. Organization, 18(4), 1-25.

Baden-Fuller, C., Haefliger, S., 2013. Business Models and Technological Innovation. Long Range Planning, 46(6), 419-426.

Batillana, J., Lee, M., Walker, J., Dorsey, C., 2012. In search of the hybrid ideal. Stanford Social Innovation Review, Summer, 51-55.

Bell, M., 1984. Learning and the accumulation of industrial technological capability in developing countries. In: Fransman, M., King, K. (Eds.), Technological Capability in the Third World. Macmillan, London, pp. 187-209.

Bell, M., Figueiredo, P. N. 2012. Building Innovative Capabilities in Latecomer Emerging Market Firms: Some Key Issues, in: Amann, E., Cantwell, J. (Eds.), Innovative Firms in Emerging Market Countries. Oxford University Press, Oxford, pp. 24-109.

Bell, M., Pavitt, K., 1993. Technological accumulation and industrial growth: contrasts between developed and developing countries. Industrial and Corporate Change, 2(2), 157-211.

Bell, M., Pavitt, K., 1995. The development of technological capabilities. In: I.U. Haque (Ed.), Trade, Technology and International Competitiveness. The World Bank, Washington, DC, pp. 69-101.

Bradley, S., McMullen, J., Artz, K., Simiyu, E., 2012. Capital is not enough: innovation in developing economies. Journal of Management Studies, 49(4), 684-717.

Calvano, L., 2008. Multinational corporations and local communities: a critical analysis of conflict. Journal of Business Ethics, 82, 793-805

Cannon, T., 1992. Corporate Responsibility. Pitman, London.

Cirera, X., Maloney, W., 2017. The Innovation Paradox. Developing-Country Capabilities and the Unrealized Promise of Technological Catch-Up. The World Bank. Washington

Cohen, W., Levinthal, D., 1990. Absorptive capacity: a new perspective on learning and innovation. Administrative Science Quarterly, 35(1), 128-152.

Cozzens, S., Sutz, J., 2014. Innovation in informal settings: reflections and proposals for a research agenda. Innovation and Development, 4(1), 5-31.

Cozzens, S., Thakur, D., 2014. Innovation and Inequality: Emerging Technologies in an Unequal World. Edward Elgar, Cheltenham and Northampton.

Dahan, N., Doh, J., Oetzel, J., Yaziji, M., 2010. Corporate-NGO collaboration: co-creating new business models for developing markets. Long Range Planning, 43(2), 326-342.

Dosi, G., Nelson, R., Winter, S., 2000. The Nature and Dynamics of Organizational Capabilities. Oxford University Press, Oxford.

Dutrénit, G., 2000. Learning and Knowledge Management in the Firm. From Knowledge Accumulation to Strategic Capabilities. Edward Elgar, Cheltenham.

Eisenhardt, K., Graebner, M., 2007. Theory building from cases: opportunities and challenges. Academy of Management Journal, 50 (1), 25-32.

Escobar, A., 2011. Sustainability: Design for the Pluriverse. Development, 54(2): 137-40.

Escobar, A., 2015. Degrowth, Post-development, and Transitions: A Preliminary Conversation. Sustainability Science, 10(3), 451-62. 
Faivre-Tavignot, B., Lehmann-Ortega, L., Moingeon, B., 2010. Le social business, laboratoire d'apprentissage des stratégies de rupture. Revue française de gestion, 9-10(208-209), 175189.

Figueiredo, P.N. 2001. Technological Learning and Competitive Performance. Edward Elgar, Cheltenham.

Figueiredo, P. N., 2011. The role of dual embeddedness in the innovative performance of MNE subsidiaries: Evidence from Brazil. Journal of Management Studies 48 (2): 417-440.

Foster, C., Heeks, R., 2013. Conceptualising Inclusive Innovation: Modifying Systems of Innovation Frameworks to Understand Diffusion of New Technology to Low-Income Consumers. The European Journal of Development Research, 25(3), 333-355.

Freeman, C., 1995. The National System of Innovation in historical perspective. Cambridge Journal of Economics, 19(1), 5-24.

George, G., McGahan, A., Prabhu, J., 2012. Innovation for inclusive growth: towards a theoretical framework and a research agenda. Journal of Management Studies, 49(4), 661-683.

Ghalib, A., Hossain, F., Arun, T., 2009. The Case of Grameen-Danone Foods Limited. Australasian Accounting, Business and Finance Journal, 3(4), 1-14.

Graham M., 2011. Time machines and virtual portals: the spatialities of the digital divide. Progress in Development Studies, 11, 211-227.

Hagedoorn, J., Cloodt, M., 2003. Measuring innovative performance: is there an advantage in using multiple indicators? Research Policy, 32(8), 1365-1379.

Hall, J., Matos, S., Sheehan, L., Silvestre, B., 2012. Entrepreneurship and innovation at the base of the pyramid: a recipe for inclusive growth or social exclusion? Journal of Management Studies, 49(4), 785-812.

Heeks, R., Foster, C., Nugroho, Y., 2014. New models of inclusive innovation for development. Innovation and Development, 4(2), 175-185.

Humberg, K., 2011. Poverty Reduction through Social Business? Lessons Learnt from Grameen Joint Ventures in Bangladesh, Euro Oekom Verlag, München, pp. 1-14.

Humberg, K., Braun, B., 2014. Social Business and Poverty Alleviation: Lessons from Grameen Danone and Grameen Veolia, in: Grove, A., Berg, G.A. (Eds.), Social Business: Theory, Practice, and Critical Perspectives. Springer, Berlin, Heidelberg, pp. 201-223.

Karnani, A., 2007. Doing well by doing good case study: 'fair and lovely' whitening cream. Strategic Management Journal, 28, 1351-1357.

Kim, L., 1997. Imitation to Innovation. The Dynamics of Korea's Technological Learning. Harvard Business School Press, USA.

Kim, L., 1998. Crisis construction and organisational learning: capability building in catching-up at Hyundai Motor. Organization Science, 9(4), 506-521.

Kogut, B., Zander, U., 1993. Knowledge of the Firm and the Evolutionary Theory of the Multinational Corporation. Journal of International Business Studies, 24(4), 625-645.

Kogut, B., Zander, U., 1996. What Firms Do? Coordination, Identity, and Learning. Organization Science, 7(5), 502-518.

Lall, S., 1980. Vertical inter-firm linkages in LDCs: an empirical study. Oxford Bulletin of Economics and Statistics, 42(3), 203-226.

Lall, S., 1992. Technological capabilities and industrialization. World Development, 20(2), 165-186.

Lee, C.-Y., 2010. A theory of firm growth: Learning capability, knowledge threshold, and patterns of growth. Research Policy, 39(2), 278-289.

Lee, K., Lim, C., 2001. Technological regimes, catching-up and leapfrogging: findings from the Korean industries. Research Policy, 30(3), 459-483. 
Leornard-Barton, D., 1995. Wellsprings of Knowledge: Building and Sustaining the Sources of Innovation. Harvard Business School Press, Boston, MA.

Lundvall, B.-A., 1992. National systems of innovation: toward a theory of innovation and interactive learning. London. Pinter Publishers, New York.

Lundvall, B.-A., Johnson, B., 1994. The learning economy. Journal of Industry Studies, 1(2), 23-42.

Mair, J., Marti, I., Ventresca, M., 2012. Building inclusive markets in rural Bangladesh: how intermediaries work institutional voids. Academy of Management Journal, 55(4), 819-850.

Malerba, F., 1992. Learning by firms and incremental technical change. The Economic Journal, 102(413), 845-859.

Miles, MB. Huberman, A.M., 1994. Qualitative Data Analysis, second ed. Sage Publications, Thousand Oaks, CA.

Murmann, J.P., 2003. Knowledge and Competitive Advantage: The Coevolution of Firms, Technology, and National Institutions. Cambridge University Press, New York.

OECD, 2005. Oslo Manual. European Commission/Eurostat, Paris.

Pansera, M., Owen, R., 2015. Framing resource-constrained innovation at the 'bottom of the pyramid': Insights from an ethnographic case study in rural Bangladesh. Technological Forecasting and Social Change, 92, 300-311.

Pansera, M., Owen, R., 2016. Innovation for de-growth: A case study of counter-hegemonic practices from Kerala, India. Journal of Cleaner Production. 1-12.

Pansera, M., Owen, R., 2018. Framing inclusive innovation within the discourse of development: Insights from case studies in India. Research Policy 47(1), 23-34.

Peerally, J., Cantwell, J., 2012. Changes in trade policies and the heterogeneity of domestic and multinational firms' strategic response: the effects on firm-level capabilities. World Development 40(3), 469-485.

Perez, C., 1988. New technologies and development. In Freeman, C., Lundvall, B., (Eds.), Small Countries Facing the Technological Revolution. Pinter Publishers, London.

Purcell, F., Toland, J., 2004. Electronic commerce for the South Pacific: A review of e-readiness. Electronic Commerce Research, 4, 241-62.

Radojevic, N., Peerally, J., 2014. Reverse innovation and the bottom of the pyramid proposition: new clothes for old garbs, in: Al-Hakim, L., Jin, C. (Eds), Quality Innovation: Knowledge, Theory, and Practices, Information Science Reference, Hershey: PA, IGI Global.

Santiago, F. 2014. Innovation for inclusive development. Innovation and Development, 4(1), 1-4.

Sardana, G. D., 2013. Social business and Grameen Danone Foods Limited. Society and Business Review, 8(2), 119-133.

Sazawal, S., Habib, A. A., Dhingra, U., Dutta, A., Dhingra, P., Sarkar, A., Black, R. E., 2013. Impact of micronutrient fortification of yoghurt on micronutrient status markers and growth - a randomized double blind controlled trial among school children in Bangladesh. BMC Public Health, 13, 514.

Siggelkow, N., 2007. Persuasion with case studies. Academy of Management Journal, 5(1), 2024.

Simanis, E., Hart, S., 2008. The Base of the Pyramid Protocol. Ithaca, NY, Cornell University: http://bop-protocol.org/, accessed March 13, 2012.

Teece, D., 2010. Business model, business strategy and innovation. Long Range Planning, 43,172194.

TEPSIE, 2014. Social Innovation Theory and Research: A Guide for Researchers.

Thompson, J., MacMillan, I., 2010. Business models: creating new markets and societal wealth. Long Range Planning, 43(2-3), 291-307. 
Tobias M. Jutta, Mair, J., Barbosa-Leiker, C. (2013). Toward a theory of transformative entrepreneuring: Poverty reduction and conflict resolution in Rwanda's entrepreneurial coffee sector. Journal of Business Venturing, 28(6), 728-742.

UNCTAD, 2016. World Investment Report, Investor Nationality: Policy Challenges, United Nations Conference on Trade and Development, United Nations Publication.

Voltan, A., De Fuentes, C., 2016. Managing multiple logics in partnerships for scaling social innovation. European Journal of Innovation Management, 19(4), 446-467.

Wernerfelt, B. 1984. A resource-based view of the firm. Strategic Management Journal, 5 (2), 171180.

Westley, $\quad$ F., 2008. The Social Innovation Dynamic. [http://sig.uwaterloo.ca/sites/default/files/documents/TheSocialInnovationDynamic_001.pdf $\% 5$ D. SIG Working Paper.

Westley, F., Antadze, N., 2010. Making a difference: strategies for scaling social innovation for greater impact. The Innovation Journal: The Public Sector Innovation Journal, 15(2), 1-18.

Yoruk, E., 2011. The influence of technological capabilities on the knowledge network component of innovation systems: evidence from advanced materials in Turkey. Int. J. Technological Learning, Innovation and Development, 4(4), 330-362.

Yunus, M., 2008. Creating a World without Poverty: Social Business and the Future of Capitalism. Public Affairs, New York.

Yunus, M., 2010. Building Social Business: The New Kind of Capitalism That Serves Humanity's Most Pressing Needs. Public Affairs, New York.

Yunus, M., Moingeon, B., Lehmann-Ortega, L., 2010. Building social business models: lessons from the Grameen experience. Long Range Planning, 43(2-3), 308-325. 


\section{Table 1. Data collection techniques and related details}

\begin{tabular}{|c|c|c|}
\hline Phases & Data collection techniques & Details \\
\hline $\begin{array}{l}\text { Exploratory } \\
\text { (June 2011) }\end{array}$ & Desk research of archival data & $\begin{array}{l}\text { All academic publications on GDFL and other social businesses including academic } \\
\text { books, working papers, peer-reviewed and non-peer reviewed journal articles and } \\
\text { Master's theses available in the public domain. Books by Yunus on social } \\
\text { businesses (Yunus, 2008, 2010). }\end{array}$ \\
\hline $\begin{array}{c}\text { Pre fieldwork } \\
\text { (Global Social Business } \\
\text { Summit, Austria, November } \\
\text { 2011) }\end{array}$ & $\begin{array}{l}\text { Four semi-structured interviews with four } \\
\text { interviewees and one informal discussion. }\end{array}$ & $\begin{array}{l}\text { Two representatives of Grameen-Uniqlo, CEO of Danone Communities, and the } \\
\text { Industrial Director of Danone Asia Pacific (Danone's designated expert in the joint- } \\
\text { venture formation and creation of GDFL). } \\
\text { One informal discussion with Muhammad Yunus. }\end{array}$ \\
\hline \multirow{4}{*}{$\begin{array}{c}\text { Main fieldwork } \\
\text { (GDFL, Bogra and Dhaka, } \\
\text { Bangladesh, February-March } \\
\text { 2012) }\end{array}$} & \multirow{3}{*}{$\begin{array}{l}\text { Twenty in-depth, semi-structured and open-ended } \\
\text { interviews with three groups of professionals. }\end{array}$} & $\begin{array}{ll}\text { Group 1: } & \begin{array}{l}\text { Industrial Director of Danone Asia Pacific; Managing Director of GDFL } \\
\text { (Dhaka based). }\end{array}\end{array}$ \\
\hline & & $\begin{array}{l}\text { Plant manager, sales manager, rural manager, intern and project } \\
\text { manager, quality and R\&D manager, production officer (there was no } \\
\text { Group 2: } \\
\text { GDFL production manager appointed at the time of fieldwork), milk } \\
\text { and farm development officer, maintenance-in-charge (there was no } \\
\text { GDFL maintenance manager appointed at the time of fieldwork), senior } \\
\text { quality control executive, junior quality control executive and seven } \\
\text { laboratory technicians. }\end{array}$ \\
\hline & & Group 3: Ex-plant Manager, present prior and during the start-up stages of GDFL \\
\hline & Non-participant observations & $\begin{array}{l}\text { These involved the observation of individuals' activities (e.g. } \\
\text { plant/sales/project/quality managers, packers, quality control employees, operators, } \\
\text { milk collectors, Grameen-Danone ladies) at work, during meetings, and on the } \\
\text { production floor. } \\
\text { These observations also took place when shadowing the industrial director of } \\
\text { Danone Asia Pacific during his tasks and especially when trouble shooting or } \\
\text { implementing tests during process and production activities. }\end{array}$ \\
\hline \multirow{3}{*}{$\begin{array}{l}\text { Post main fieldwork (March to } \\
\text { May 2012) }\end{array}$} & $\begin{array}{l}\text { Consultation of Danone and GDFL's files and } \\
\text { archival records. }\end{array}$ & $\begin{array}{l}\text { All material gathered in the form of annual reports, internal bulletins and } \\
\text { newspapers, copies of staff's presentations, Danone Communities website. }\end{array}$ \\
\hline & $\begin{array}{l}\text { Two informal discussions at the Danone } \\
\text { Communities Conference in Paris. }\end{array}$ & $\begin{array}{l}\text { Danone's Vice-Chairman of the Board of Directors. } \\
\text { CEO of Danone Communities. }\end{array}$ \\
\hline & $\begin{array}{l}\text { Follow-up semi-structured interview for the } \\
\text { confirmation of important statements and the } \\
\text { validation of critical events and emerging constructs } \\
\text { from our study. }\end{array}$ & Industrial Director of Danone Asia Pacific. \\
\hline
\end{tabular}


Figure 1. Integrating the TC and inclusive innovation literatures

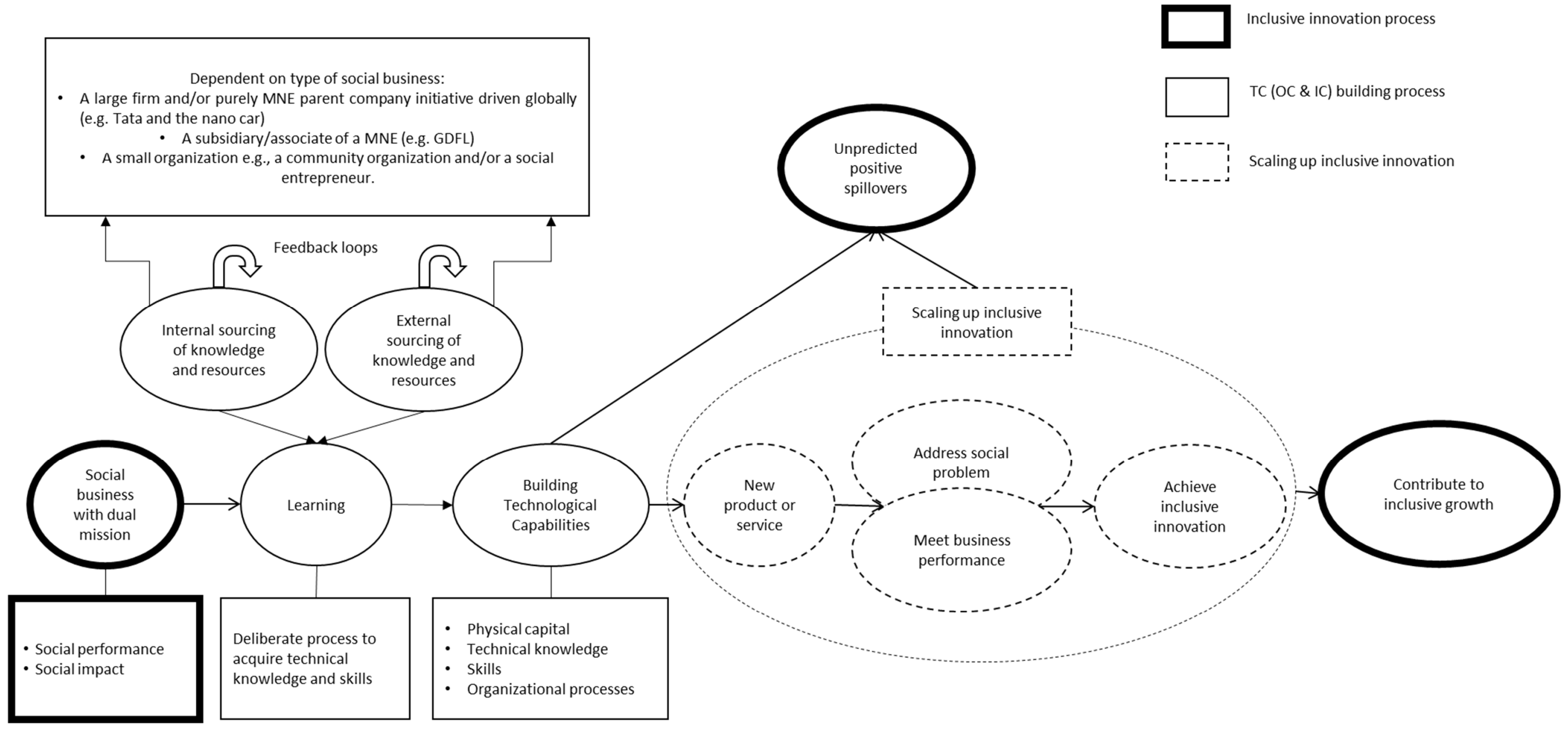

Based on the authors' own elaboration. 


\section{Figure 1. Integrating the $\mathrm{TC}$ and inclusive innovation literatures}

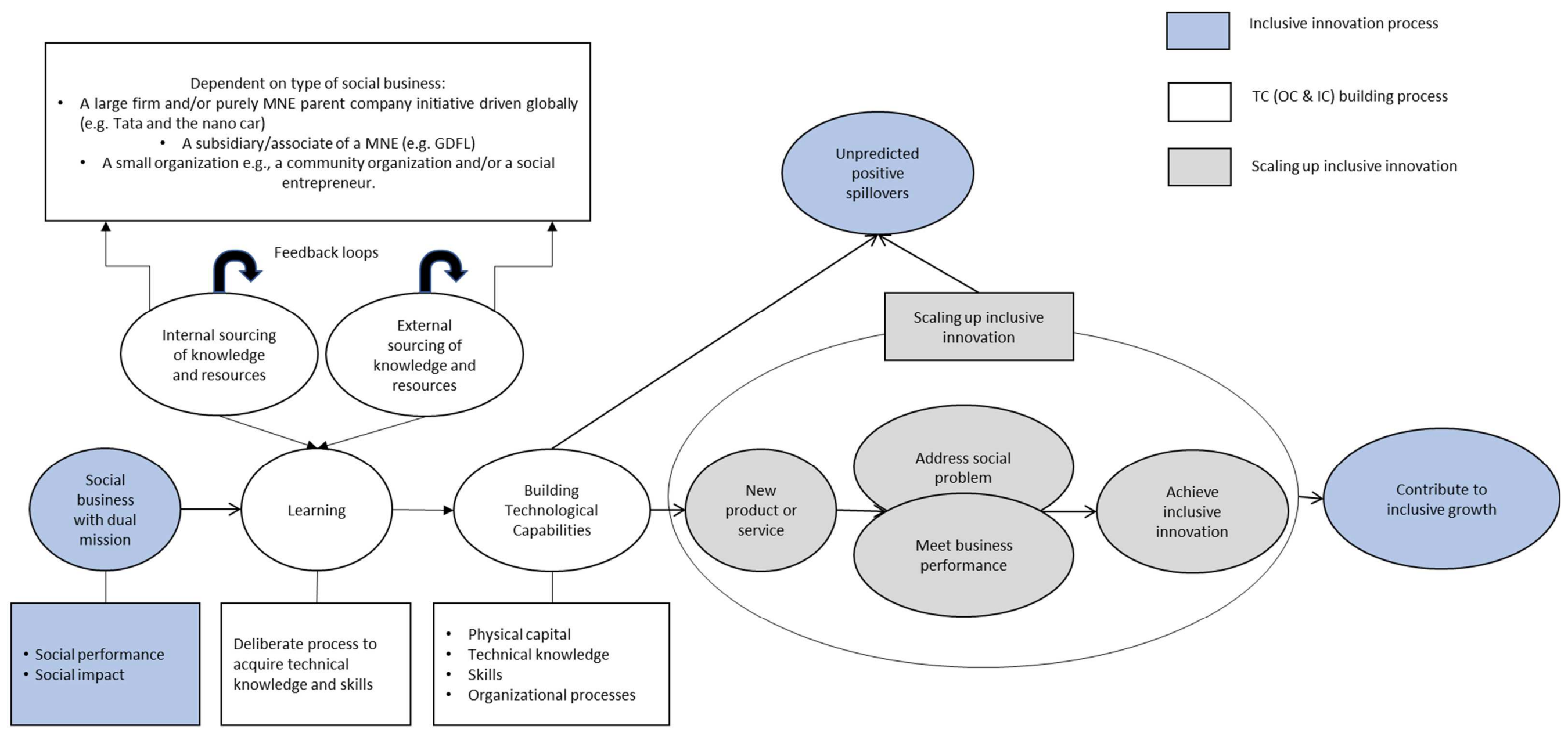

Based on the authors' own elaboration. 
Figure 2. A framework for assessing TC building in a social business of the dairy industry

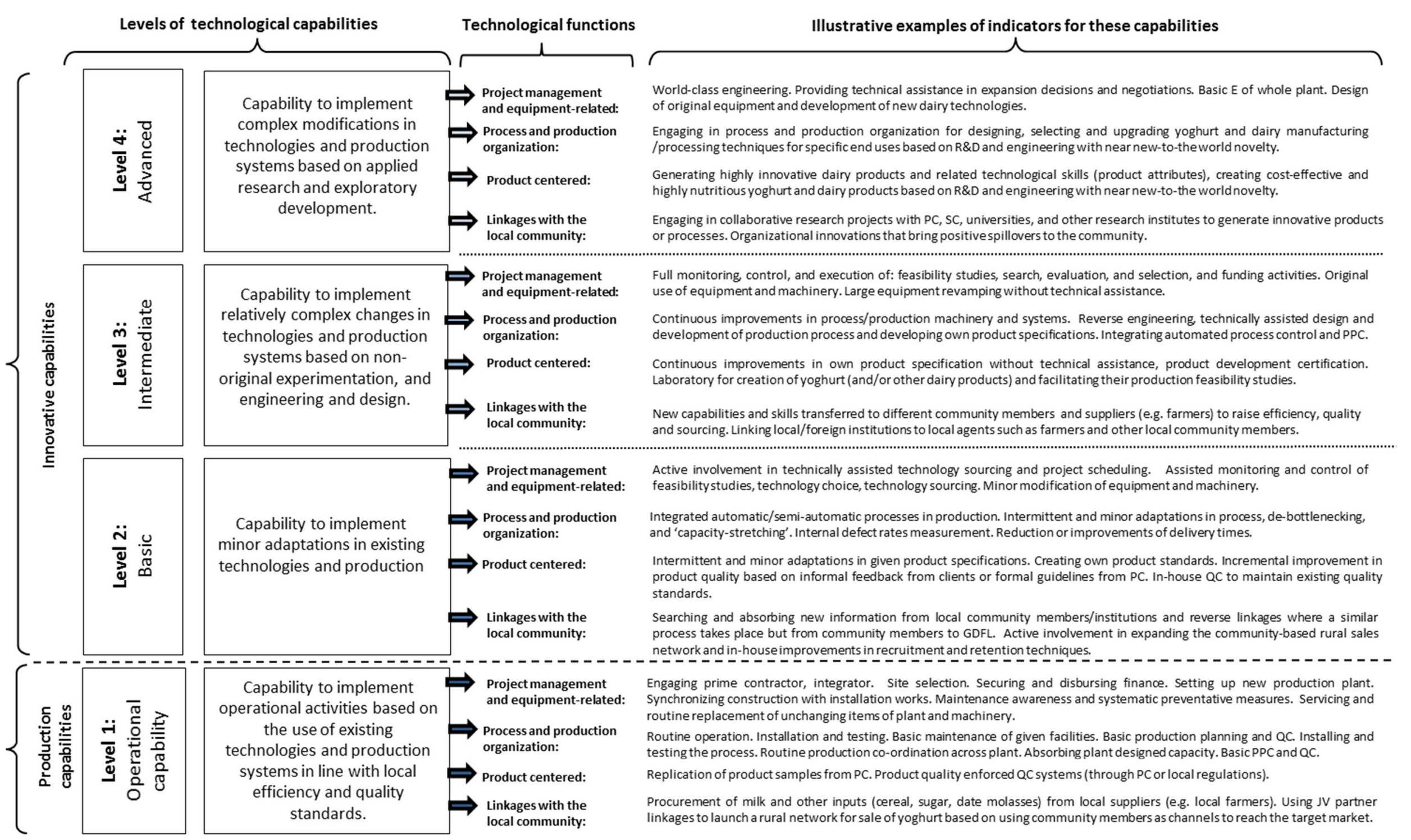

Sources: Adapted from Lall (1992), Bell and Pavitt (1995), and Figueiredo $(2001,2011)$ and based on authors' own research and elaboration.

Keys: $\mathrm{E}=$ engineering; $\mathrm{PPC}=$ production planning and control; $\mathrm{QC}=$ quality control; $\mathrm{PC}=$ parent company; $\mathrm{SC}=$ sister company. 
Figure 2. A framework for assessing TC building in a social business of the dairy industry

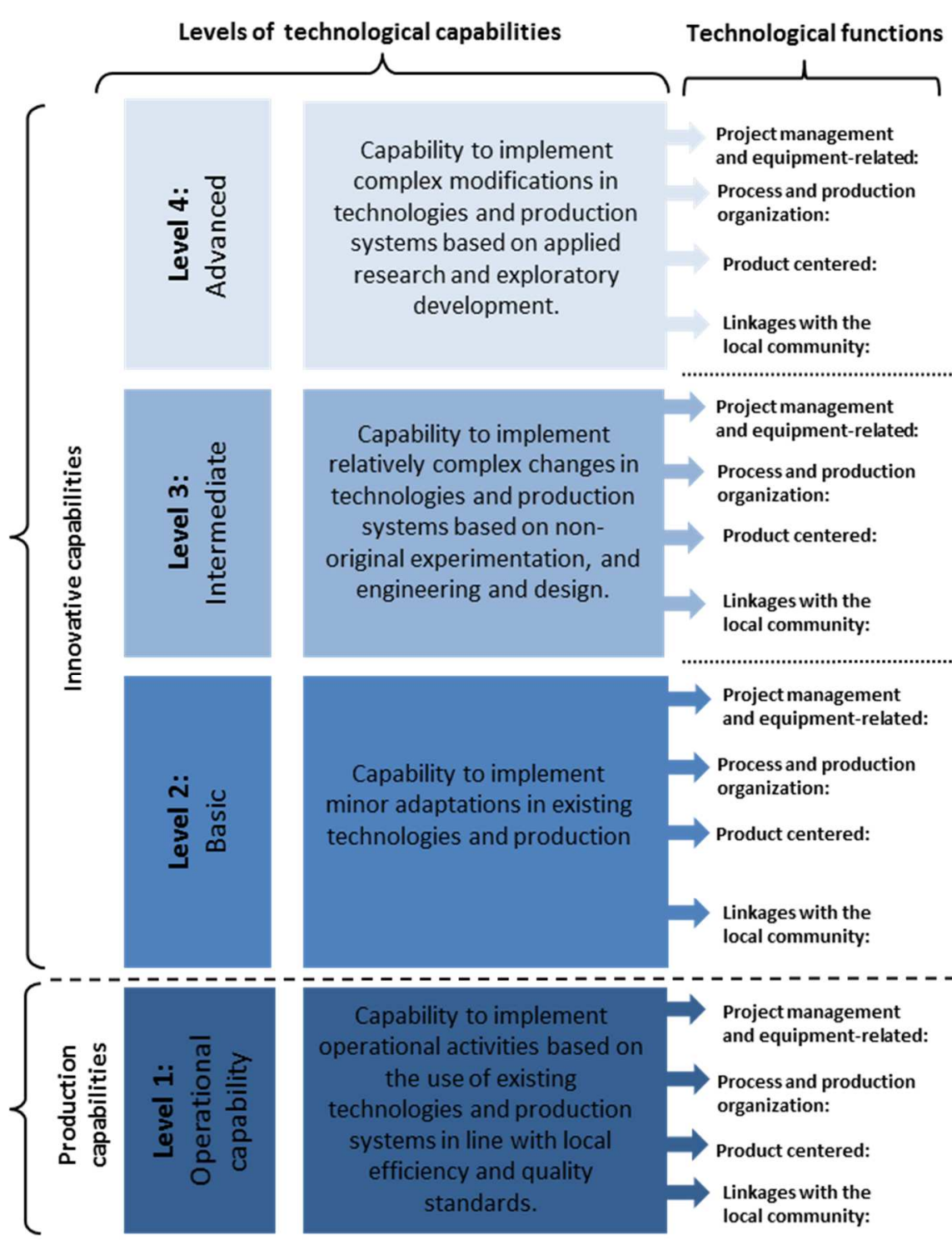


Figure 3. TC building for project management and equipment-related activities at GDFL

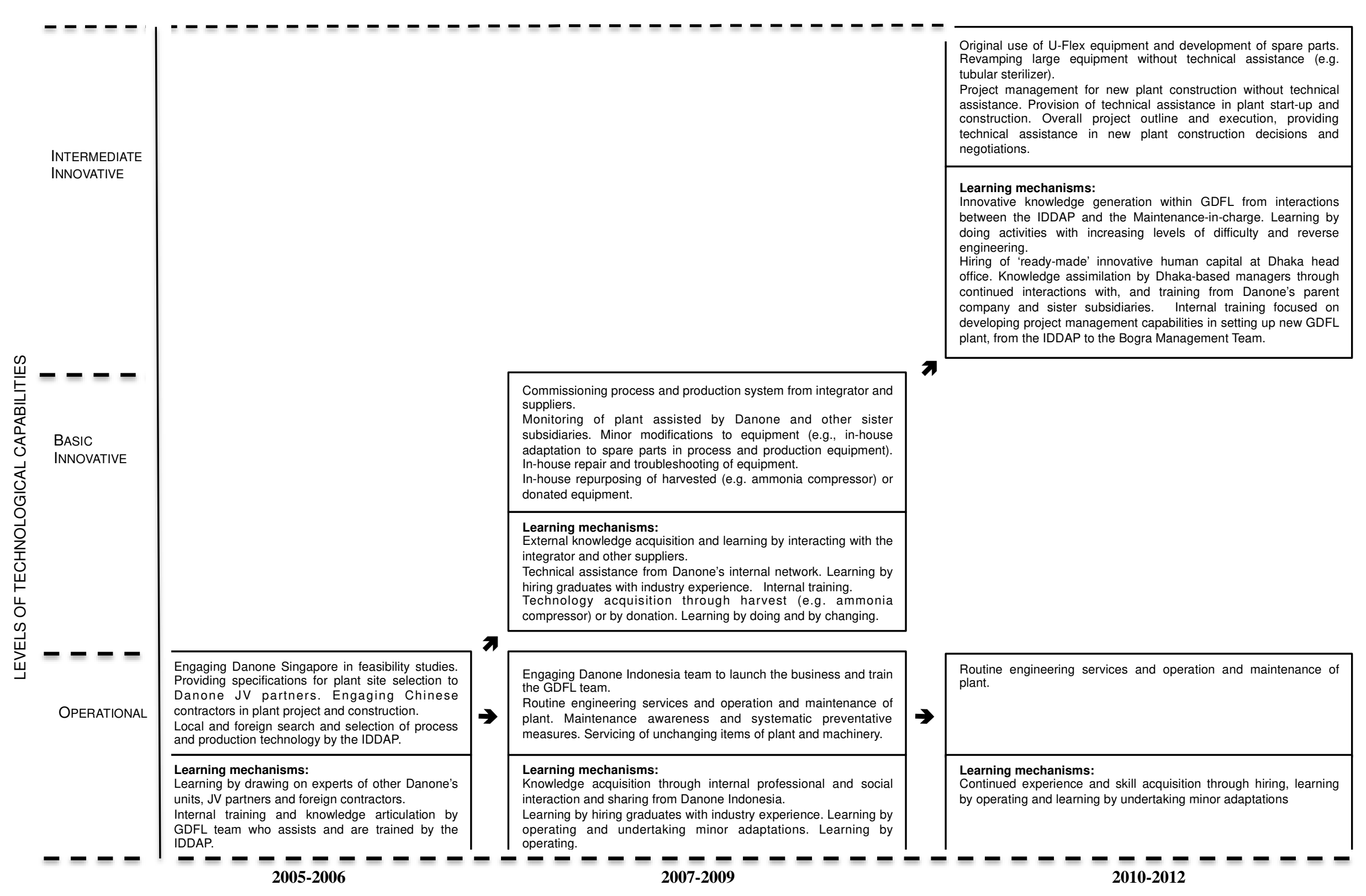

Source: Derived from the empirical study. 
Figure 3. TC building for project management and equipment-related activities at GDFL

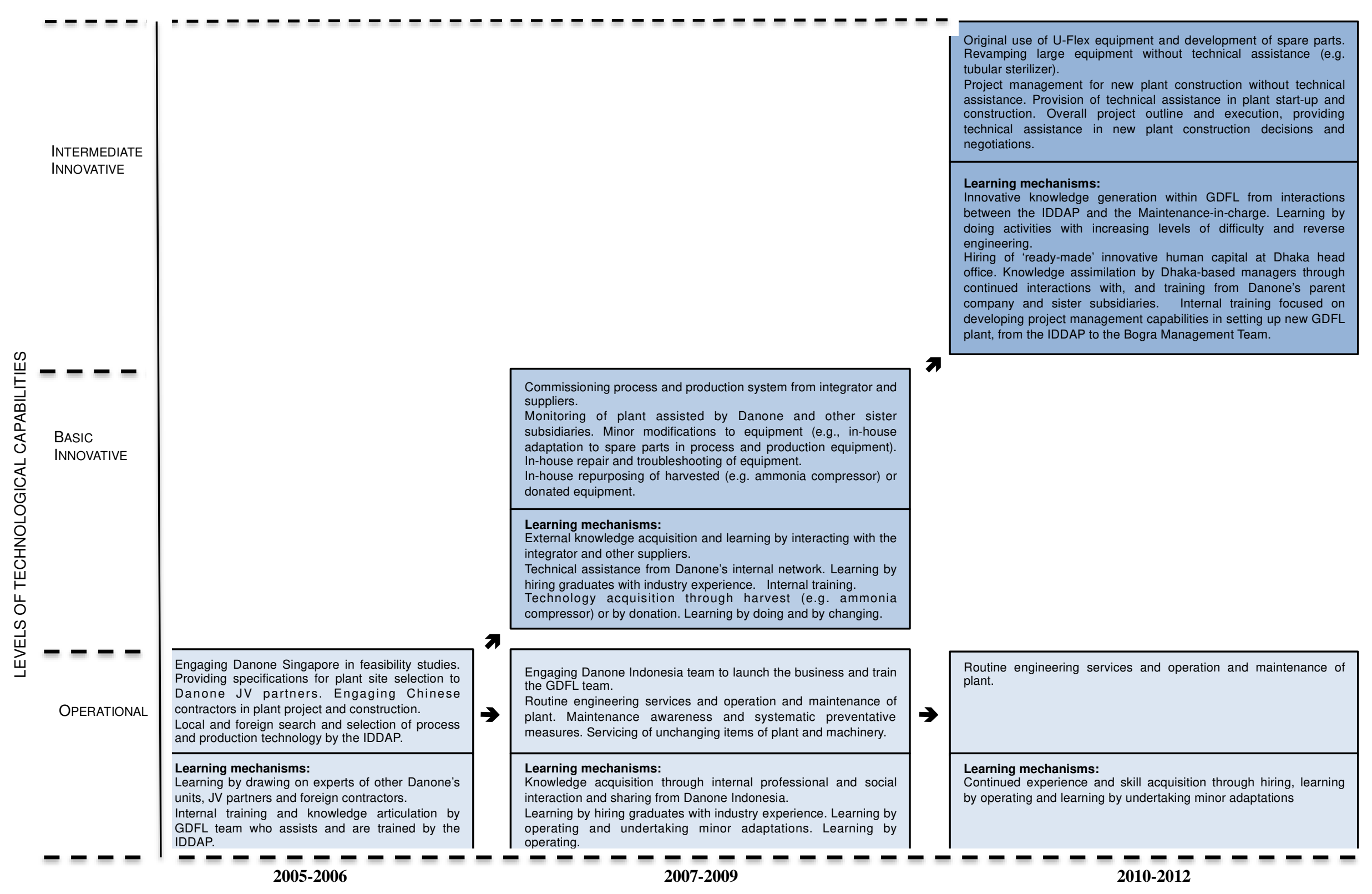

Source: Derived from the empirical study 
Figure 4. TC building for process and production organization activities at GDFL

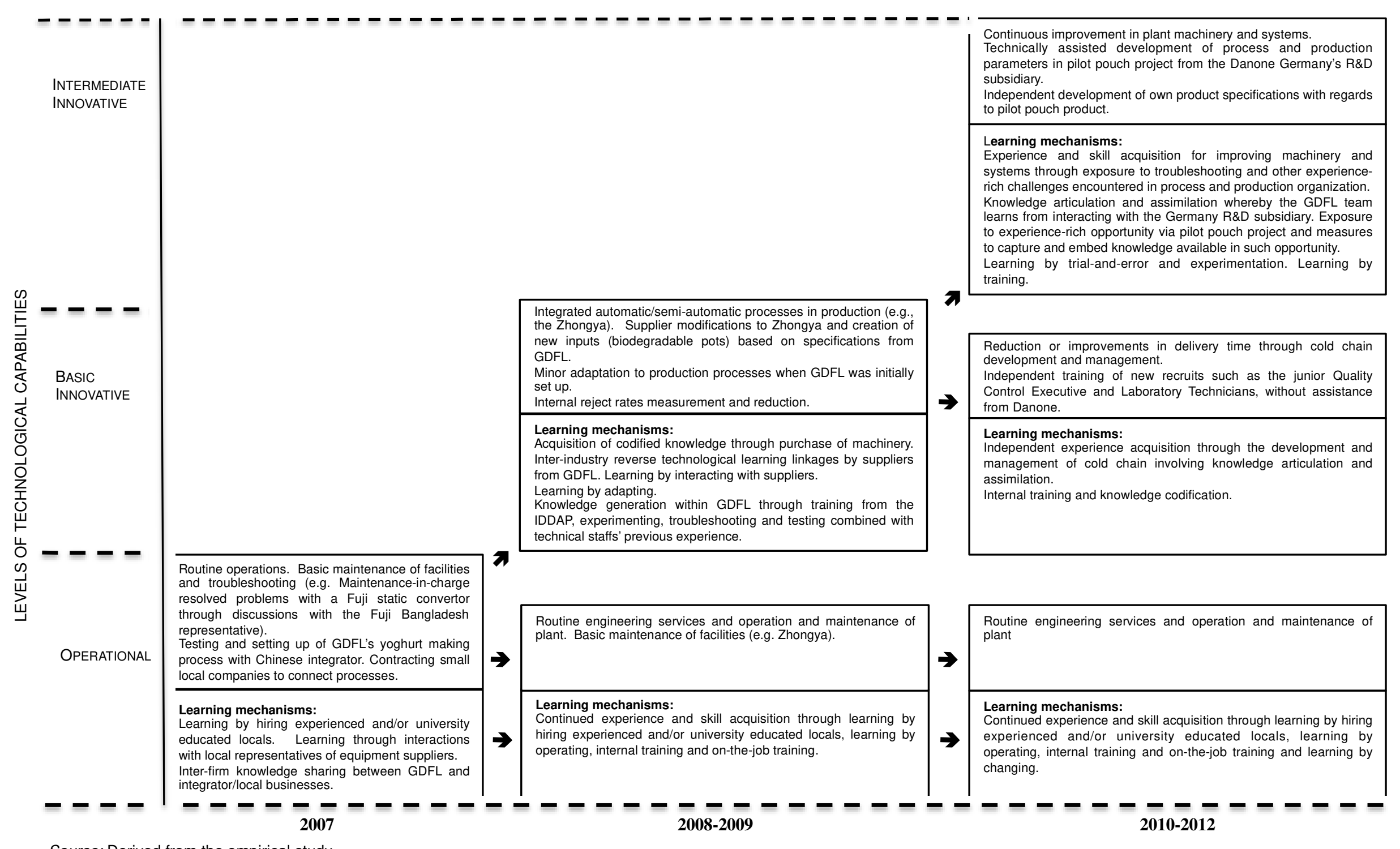

Source: Derived from the empirical study. 
Figure 4. TC building for process and production organization activities at GDFL

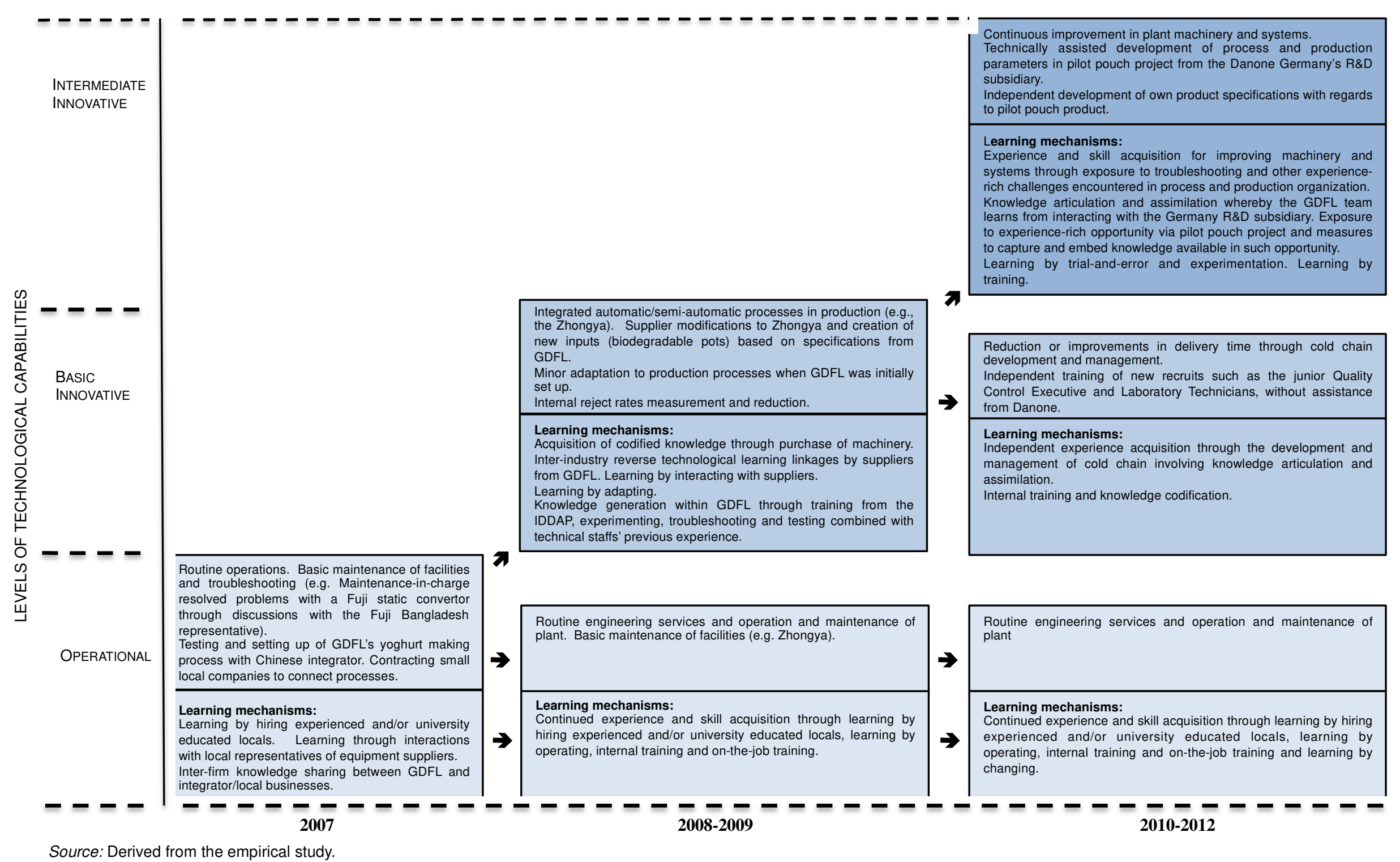


Figure 5. TC building for product-centered activities at GDFL

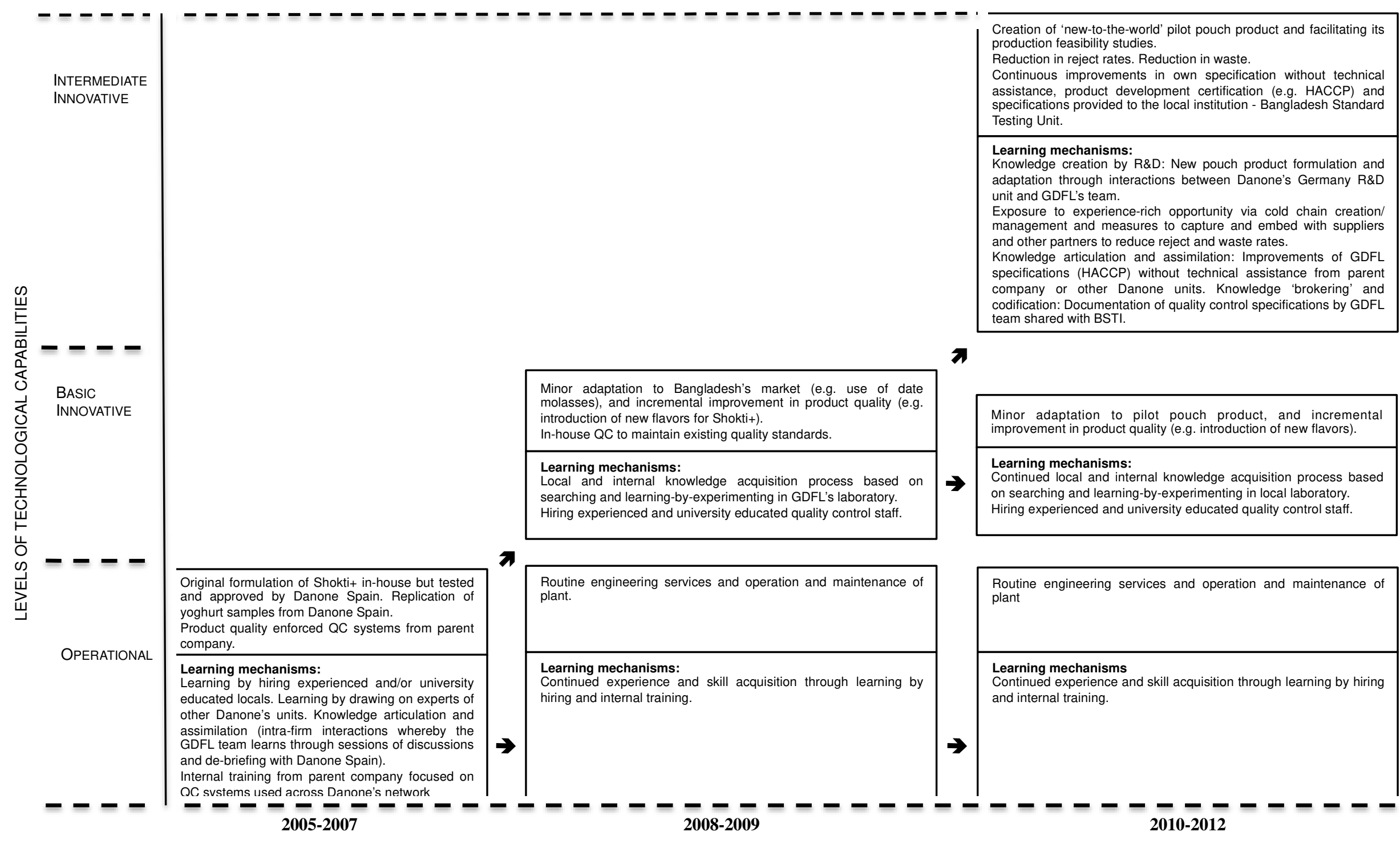

Source: Derived from the empirical study. 
Figure 5. TC building for product-centered activities at GDFL

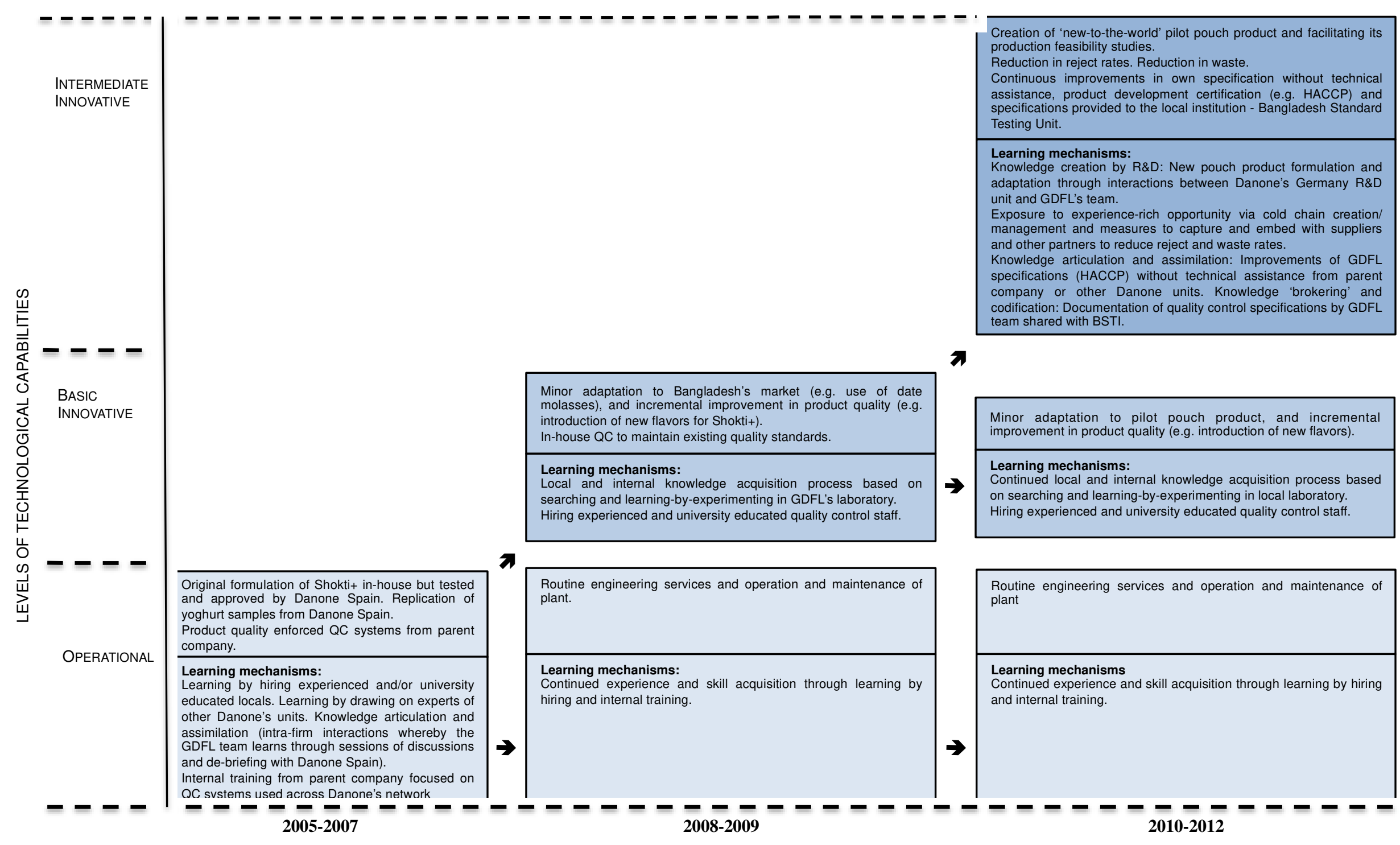

Source: Derived from the empirical study. 


\section{Figure 6. Developing linkages with the local community}

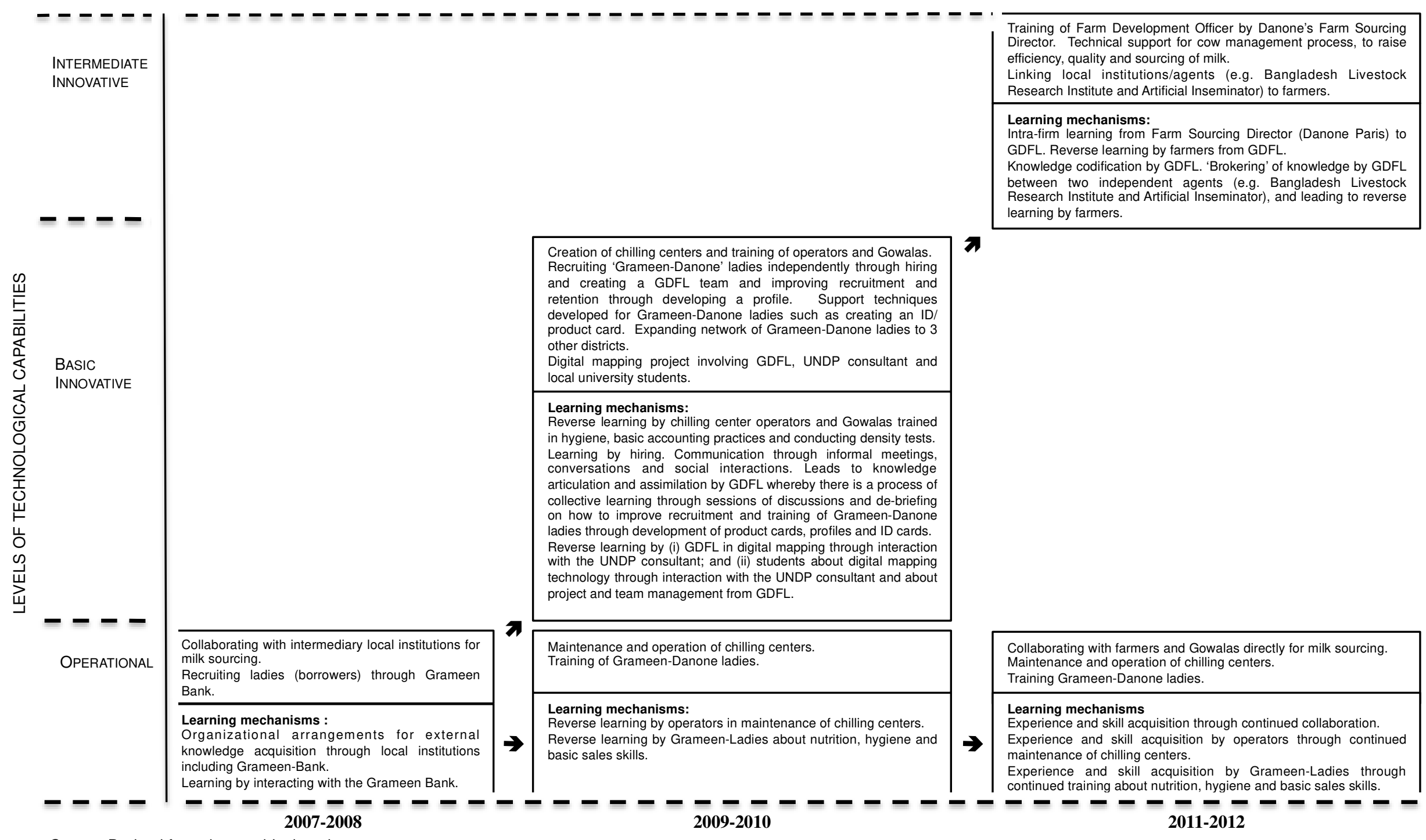

Source: Derived from the empirical study. 
Figure 6. Developing linkages with the local community

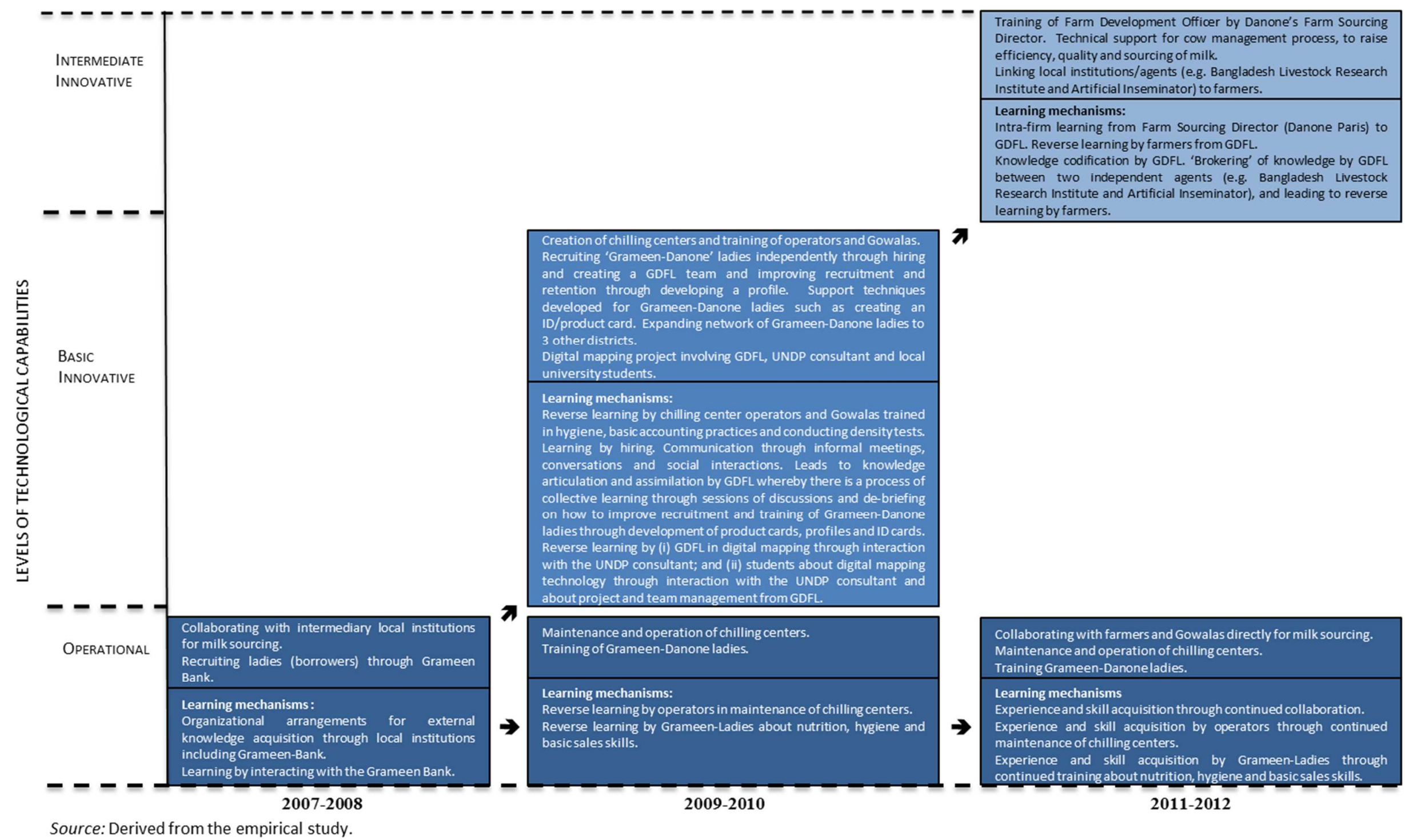

